\title{
Article
}

\section{Fate of Nitrogen from Artichoke (Cynara cardunculus L. var. scolymus (L.)) Crop Residues: A Review and Lysimeter Study}

\author{
Nouraya Akkal-Corfini ${ }^{1, *}\left(\mathbb{D}\right.$, Paul Robin ${ }^{1}\left(\mathbb{D}\right.$, Safya Menasseri-Aubry ${ }^{1}$, Michael S. Corson ${ }^{1} \mathbb{D}$, Jean Paul Sévère ${ }^{2}$, \\ Jean Michel Collet ${ }^{3}$ and Thierry Morvan ${ }^{1}$ \\ 1 SAS, INRAE, Agrocampus Ouest, F-35000 Rennes, France; Paul.robin@inrae.fr (P.R.); \\ safya.menasseri@agrocampus-ouest.fr (S.M.-A.); michael.corson@inrae.fr (M.S.C.); \\ thierry.morvan@inrae.fr (T.M.) \\ 2 Comité d'Action Technique et Économique, Station Expérimentale Légumière et Horticole de Vézendoquet, \\ F-29250 Saint-Pol-de-Léon, France; jean-paul.severe@cate.bzh \\ 3 Ctifl-Caté, Station Expérimentale Légumière et Horticole de Vézendoquet, F-29250 Saint-Pol-de-Léon, France; \\ jean-michel.collet@cate.bzh \\ * Correspondence: nouraya.akkal-corfini@inrae.fr
}

check for updates

Citation: Akkal-Corfini, N.; Robin, P.; Menasseri-Aubry, S.; Corson, M.S.; Sévère, J.P.; Collet, J.M.; Morvan, T. Fate of Nitrogen from Artichoke (Cynara cardunculus L. var. scolymus (L.)) Crop Residues: A Review and Lysimeter Study. Nitrogen 2021, 2, 41-61. https://doi.org/10.3390/ nitrogen2010004

Received: 2 December 2020

Accepted: 19 January 2021

Published: 1 February 2021

Publisher's Note: MDPI stays neutral with regard to jurisdictional claims in published maps and institutional affiliations.

Copyright: (c) 2021 by the authors. Licensee MDPI, Basel, Switzerland. This article is an open access article distributed under the terms and conditions of the Creative Commons Attribution (CC BY) license (https:/ / creativecommons.org/licenses/by/ $4.0 /)$.

\begin{abstract}
The goal of the European Nitrate Directive 91/676/CEE is to mitigate or prevent water pollution associated with the nitrogen $(N)$ cascade. Vegetable crops have a high risk of nitrate leaching during autumn and winter. Information about the fate of $N$ from artichoke (Cynara cardunculus L. var. scolymus (L.)) residues is reviewed and then supplemented with a three-year study with ${ }^{15} \mathrm{~N}$ labelled residues in an artichoke-cauliflower (Brassica oleracea L. cv. botrytis) rotation in six lysimeters. After three years, $6 \%$ of $N$ in artichoke residues was leached, $8 \%$ was exported by crops, while $86 \%$ remained in the lysimeter. Summed over the rotation, $16 \%$ of artichoke-residue $N$ was absorbed by artichoke and $14 \%$ by cauliflower. Total aboveground $N$ uptake by all crops during the entire rotation ranged from 370 to $534 \mathrm{~kg} \mathrm{~N} \mathrm{ha}^{-1}$, of which $207-311 \mathrm{~kg} \mathrm{~N}^{-1}$ haturned to the soil as residues. Increasing $N$-recycling efficiency and reducing the risk of $N$ leaching while conserving crop productivity requires capturing $N$ mineralized from soil organic $N$. Cauliflower performs this capture effectively during the drainage period. A break crop should be introduced after the first and second harvests of artichoke to further synchronize $N$ mineralization and uptake and reduce leaching risk during the rotation.
\end{abstract}

Keywords: ${ }^{15} \mathrm{~N}$; artichoke residues; lysimeter; mineralization; nitrogen recovery; nitrate leaching

\section{Introduction}

Nitrogen $(N)$ fertilizers have increased the yield and quality of vegetable crops and thereby stimulated their genetic progress. In many agricultural areas of the world, however, increased nitrate loading of surface waters and groundwater has contaminated drinking water resources and caused eutrophication of freshwaters and coastal marine ecosystems [1,2]. Northern coasts of Brittany, France, regularly experience green algae blooms due to high nitrate concentrations in soil and groundwater that make their way to the ocean in surface water. High soil nitrate concentrations come from high fertilization or mineralization of soil organic matter (SOM), which releases $N$ that at times is out of sync with crop needs. Vegetable production areas in this region traditionally practice intensive rotations that include artichokes, cauliflower, cabbage, potatoes, onions and shallots. Vegetable cropping systems have short-term production cycles and long-term rotations. Vegetable crops require (1) high $N$ availability to achieve the product quality required by market demand and (2) frequent tillage, which increases SOM mineralization, leading to a high risk of $N$ leaching during rainy periods.

Increasing $N$-use efficiency in vegetable cropping systems is crucial to maintain farm productivity and revenue, keep food production close to populations and decrease environmental impacts. The target of such improvement is better synchronization between soil 
mineralization and vegetable $N$ uptake $[3,4]$. One mechanism for action is complementarity between crops. Choosing which break crop to grow during drainage periods requires crop-specific knowledge about dynamics of $N$ availability from crop residues and soils as a function of time and climate.

Nearly $85 \%$ of the world's globe artichokes (Cynara cardunculus L. var. scolymus (L.)) are produced in Europe [5-7]. They are cultivated on more than 9500 ha [8], which is approximately $75 \%$ of the total world area [9]. France ranks fourth in European production, producing 42,465 $\mathrm{t}$ of artichokes on 7721 ha in 2013 [10]; 90\% of the French artichoke area is located in Brittany. The part of the plant marketed is the immature composite inflorescence (head or capitulum), with edible fleshy leaves (bracts) and receptacle $[5,11]$. Artichoke heads are harvested along with the floral stem and include 2-3 leaves at the marketing stage, regardless of size [12]. Most of the plant returns to the soil as chopped residues.

Artichoke is perceived as a healthy, nutritious vegetable [13]. It is rich in inulin, fiber, minerals and, in particular, polyphenols [14]; is a source of biophenols; and its leaf extracts have been widely used in herbal medicine as hepatoprotectors and choleretics since ancient times $[11,15]$. Artichoke extracts have been shown to produce various pharmacological effects, such as inhibition of cholesterol biosynthesis and low-density lipoprotein oxidation [16].

The artichoke is an herbaceous perennial plant with an annual growth cycle $[17,18]$ and a deep root system. In Brittany, artichokes are produced for only 3-4 years in a row because production decreases significantly after three years. The artichoke crop is often rotated with cauliflower (Brassica oleracea L. cv. botrytis), which has residues particularly high in $N$ [4].

The artichoke cycle lasts seven months during the first year and 11-12 months during the second and third years. Artichoke develops during winter and spring and is ready for harvest in summer, when it is still growing rapidly $[11,19,20]$. During autumn and winter, the plant remains in the vegetative growth stage (i.e., a rosette without a head). Therefore, increasing $N$-use efficiency requires specific knowledge to analyze separately the fate of $N$ from residues of each successive artichoke crop. Artichokes can achieve high annual yields [11,21] and take up large amounts of $N$ (e.g., $400 \mathrm{~kg} \mathrm{~N} \mathrm{ha}^{-1}$ ) [22]. The artichoke's deep and efficient root system takes advantage of soil $N$ at depth, decreasing $N$ leaching and soil and groundwater pollution [23]. After each artichoke harvest, farmers cut aboveground biomass because of its sensitivity to frost and to allow new stems to grow in spring. They leave the soil with only stumps during autumn and part of the winter. Therefore, most artichoke biomass and $N$ absorbed by plants return to the soil as residues. Total $N$ in artichoke residues ranges from 1.43 to $3.07 \mathrm{~g} \mathrm{~kg}^{-1}$, depending on the amount of $N$ fertilizer applied [24]. Excessive $N$ fertilization leads to $N$ accumulation in plants [25], which increases biomass without increasing the yield [26]. It also increases mineralization of organic $N$ and carbon (C) [26]. Through mineralization, vegetable residues can release $20-80 \%$ of the $N$ a few weeks after their incorporation into the soil $[27,28]$. In crop rotations, this represents a potential source of available $N$ for the following crop [4,29] but also a potential risk of nitrate leaching, especially when residue incorporation is followed by bare soil during a drainage period $[30,31]$. This practice is unlike that for the cultivation of Madeira cardoon (Cynara cardunculus var. ferocissima) for bioenergy, which keeps the soil covered throughout most of the year, minimizing the risk of soil erosion [32] and leaching during the drainage period (autumn and winter). To reduce residue $N$ leaching into groundwater, it is important to consider this mineralized $N$ when applying fertilizers. In agricultural systems, past applications of mineral fertilizers and $N$ from crop residues, as well as the $N$-retention capacity of the soil, must be considered to reduce emissions of nitrate from agriculture to aquatic systems $[2,33]$.

$N$ from crop residues that becomes available to a subsequent crop has been estimated by labeling plants with ${ }^{15} \mathrm{~N}$ [34-37]. Monitoring ${ }^{15} \mathrm{~N}$ over several years in multiple soil and plant pools helps quantify $N$ availability, recycling and losses in response to application 
of fresh plant material [38]. Several studies have been performed to trace $N$ dynamics in natural ecosystems and agricultural systems [39,40], but few of them occurred in vegetablecropping systems. Information on recovery of ${ }^{15} \mathrm{~N}$ in residues by crops beyond the first year of application remains scarce, since most studies measure only recovery of residue $N$ by the first crop following application [33]. Few studies have investigated the turnover and availability of $N$ applied as plant residues using ${ }^{15} \mathrm{~N}$ at the rotation scale $[4,41]$.

The aim of this study was to review the fate of $N$ from artichoke residues and to supplement existing knowledge by monitoring the fate of incorporated ${ }^{15} \mathrm{~N}$-labeled artichoke residues in a lysimeter experiment in an artichoke-cauliflower crop rotation. Since the production cycle of artichoke has three successive annual harvests, the protocol was adapted to separate the fate of $N$ from each harvest's residues.

\section{Materials and Methods}

\subsection{Lysimeter Site History and Experimental Conditions}

The experiment was conducted from 1998 to 2004 at the Committee of Technical and Economic Action experimental station $\left(48.65^{\circ} \mathrm{N}, 3.98^{\circ} \mathrm{W}\right)$ in Brittany, France, in six lysimeters $(2.5 \mathrm{~m}$ in diameter at a depth of $2 \mathrm{~m})$. Lysimeter soil was derived from an aeolien loam (Epianthric Luvisol) [42] with 15\% clay, $60 \%$ silt and 25\% sand; a mean pH of 6.87 (range 6.79-7.01); a mean organic matter content of $2.66 \%$ (range $2.55-2.71 \%$ ) and a mean organic $N$ content of $0.14 \%$ (range $0.13-0.15 \%$ corresponding to $5300-6200 \mathrm{~kg} \mathrm{~N} \mathrm{ha}^{-1}$ ). The lysimeters were cultivated with cauliflower/artichoke rotations for 6 years (1992-1998) prior to the experiment. The variety of artichoke used was "Camus de Bretagne, clone no. 46", which represents $80 \%$ of artichoke production in France. For cauliflower, the "Jaouen hybride F1" was used, which is representative of January and February production.

\subsection{Experimental Design}

We followed three artichoke cycles (ART1, ART2 and ART3) and mineralization of their ${ }^{15} \mathrm{~N}$-labeled residues ( $\mathrm{R}_{\mathrm{ART} 1}, \mathrm{R}_{\mathrm{ART} 2}$ and $\mathrm{R}_{\mathrm{ART} 3}$, respectively) (Figure 1$)$. The $N$ contribution of residues of each artichoke cycle was estimated for the artichoke-cauliflower rotation (ART1-ART2-ART3-cauliflower) for each residue (i.e., $\mathrm{R}_{\mathrm{ART} 1}, \mathrm{R}_{\mathrm{ART} 2}$ and $\mathrm{R}_{\mathrm{ART}}$ ) and then summed to estimate total artichoke contribution to the rotation.

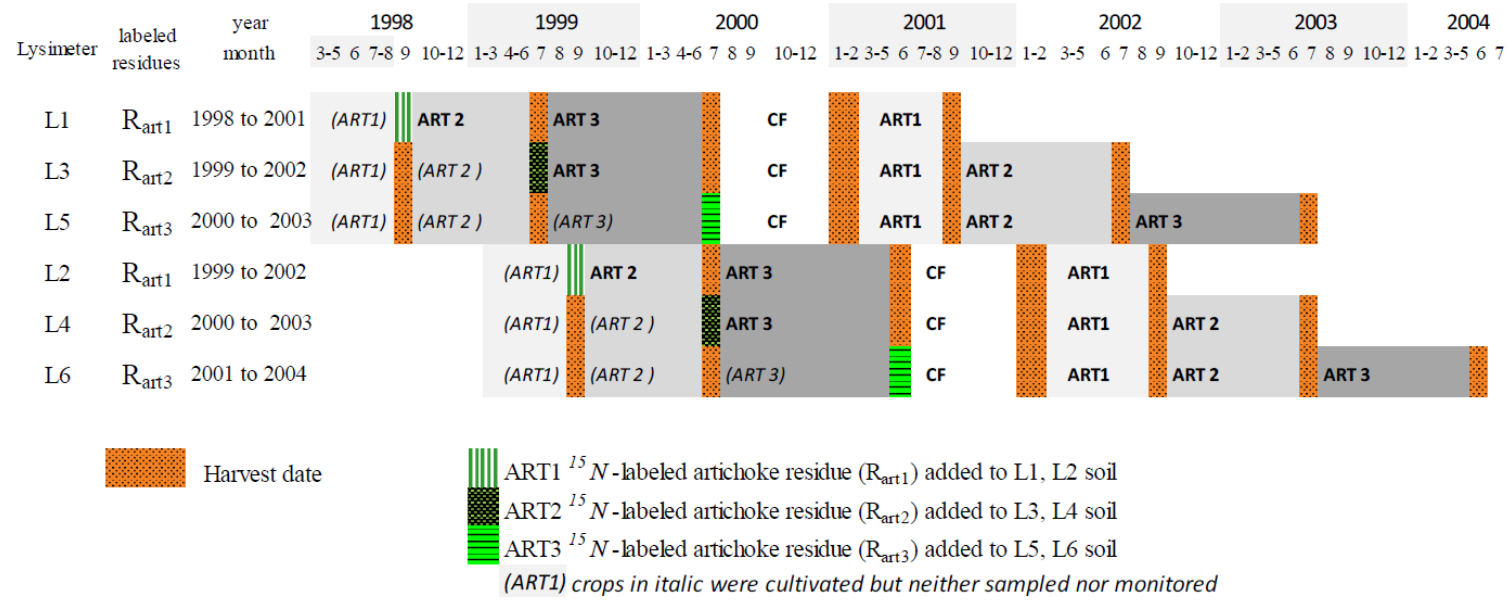

Figure 1. Crop rotations in six lysimeters (L1 to L6) and ${ }^{15} \mathrm{~N}$-labeled artichoke (ART) residues applied to soil ( $\mathrm{R}_{\text {ART1 }}$, $\mathrm{R}_{\text {ART2 }}$ and $\left.\mathrm{R}_{\mathrm{ART} 3}\right)$ in ART-cauliflower $(\mathrm{CF})$ rotations.

Lysimeters receiving the same artichoke residues (L1-L2 for $\mathrm{R}_{\mathrm{ART} 1}$, L3-L4 for $\mathrm{R}_{\mathrm{ART}}$ and L5-L6 for $\mathrm{R}_{\mathrm{ART} 3}$ ) were established with a one-year time lag. This approach aimed to minimize weather risks and to avoid losing an artichoke cycle in the artichoke-cauliflower rotation. This allowed us to follow at least one of the two lysimeters each year, in case one of them had a problem. The experimental design did not include replicates of each 
treatment because only six lysimeters were available, but it was repeated in time, with the one-year time lag between treatments, for a total of six years. Consequently, differences in annual weather were part of the variability in results. Differences observed between artichoke cycles or between artichoke and cauliflower due to differences in the weather, as well as average results based on the six lysimeters observed during the six years, can be considered representative of current practices in the region.

\subsection{Production, Analysis and Incorporation of ${ }^{15} \mathrm{~N}$-Labeled Artichoke Plants}

Artichoke plants labeled with ${ }^{15} N$ were planted $\left(10,000\right.$ plants ha $\left.{ }^{-1}\right)$ in a field near the lysimeters on 29 April 1998 for lysimeters L1/L3/L5 and on 30 April 1999 for lysimeters L2/L4/L6. Thirteen applications of ${ }^{15} \mathrm{~N}$ in a solution of ammonium nitrate enriched with 10 atom $\%$ excess were performed over the three years of artichoke cycles. Applications of ${ }^{15} \mathrm{~N}$ were followed by soil tillage at a depth of $10 \mathrm{~cm}$ to decrease volatilization losses.

Artichoke plants were harvested on different dates (Figure 1), and plant biomass was sampled separately as stems and leaves (Table 1). Plant parts were dried at $60{ }^{\circ} \mathrm{C}$ to measure dry matter (DM) content, and a subsample was finely ground for chemical analyses. Total $C$ and $N$ contents and ${ }^{15} N$ atom $\%$ excess were analyzed by total combustion with an elementary analyzer (C. E. 1500 NA, Carlo Erba, Milan, Italy) interfaced with an isotope ratio mass spectrometer (Optima, Micromass, Cheshire, UK).

Table 1. $\mathrm{C} / \mathrm{N}$ ratio, ${ }^{15} \mathrm{~N}$ concentration and amounts of dry matter (DM) and $N$ of ${ }^{15} \mathrm{~N}$-labeled artichoke leaves and stems incorporated into lysimeter soil.

\begin{tabular}{|c|c|c|c|c|c|c|c|}
\hline Lysimeter & $\begin{array}{l}\text { Labeled } \\
\text { Residues }\end{array}$ & $\begin{array}{l}\text { Artichoke } \\
\text { Part }\end{array}$ & $\begin{array}{c}N \\
(\% \mathrm{DM})\end{array}$ & $\begin{array}{c}C / N \\
\text { Ratio }\end{array}$ & $\begin{array}{c}{ }^{15} N \\
(\delta \% \\
\text { Excess })\end{array}$ & $\begin{array}{c}\text { DM } \\
\left(\mathrm{g} \mathrm{m}^{-2}\right)\end{array}$ & $\begin{array}{c}N \\
(\mathrm{~kg} \mathrm{~N} \mathrm{~N} \\
\left.\mathrm{ha}^{-1}\right)\end{array}$ \\
\hline \multirow[t]{2}{*}{ L1 } & \multirow[t]{2}{*}{$\mathrm{R}_{\mathrm{ART} 1}$} & leaves & 2.29 & 19.9 & 1.95 & 315 & 72 \\
\hline & & stems & 0.71 & 71.0 & 1.72 & 341 & 24 \\
\hline \multirow[t]{2}{*}{$\mathrm{L} 2$} & \multirow[t]{2}{*}{$\mathrm{R}_{\mathrm{ART} 1}$} & leaves & 2.13 & 20.5 & 2.34 & 292 & 62 \\
\hline & & stems & 0.67 & 57.7 & 2.11 & 377 & 25 \\
\hline \multirow[t]{2}{*}{ L3 } & \multirow{2}{*}{$\mathrm{R}_{\mathrm{ART} 2}$} & leaves & 1.77 & 23.3 & 1.19 & 266 & 47 \\
\hline & & stems & 0.48 & 80.6 & 0.98 & 197 & 9 \\
\hline \multirow[t]{2}{*}{$\mathrm{L} 4$} & \multirow[t]{2}{*}{$\mathrm{R}_{\mathrm{ART} 2}$} & leaves & 1.89 & 20.0 & 1.95 & 197 & 37 \\
\hline & & stems & 0.59 & 70.2 & 1.73 & 150 & 9 \\
\hline \multirow[t]{2}{*}{ L5 } & \multirow{2}{*}{$\mathrm{R}_{\mathrm{ART} 3}$} & leaves & 1.75 & - & 2.02 & 272 & 48 \\
\hline & & stems & 0.44 & - & 1.82 & 209 & 9 \\
\hline \multirow[t]{2}{*}{ L6 } & \multirow[t]{2}{*}{$\mathrm{R}_{\mathrm{ART} 3}$} & leaves & 1.74 & 23.9 & 2.62 & 310 & 54 \\
\hline & & stems & 0.55 & 77.6 & 2.54 & 269 & 15 \\
\hline
\end{tabular}

One day after harvesting ${ }^{15} \mathrm{~N}$-labeled artichoke plants, all aboveground biomass of non-labeled artichoke plants grown on the lysimeters was removed and replaced by the same amount of mixed stems and leaves of the ${ }^{15} \mathrm{~N}$-labeled artichoke residues, which then was incorporated into the upper $10 \mathrm{~cm}$ of the soil in each lysimeter (Table 1) according to current farm practices.

\subsection{Crop Rotations and Practices on Lysimeters}

Artichoke-cauliflower crop rotations continued on the lysimeters over the next three years (Figure 1). To ensure representative yields and biomass production and to improve estimates of $N$ bioavailability in artichoke residues and leaching losses during the experiment, moderate fertilization was applied: ART1, ART2, and ART3 were fertilized with ammonium nitrate $\left(105 \mathrm{~kg} \mathrm{~N} \mathrm{ha}^{-1}\right)$ on two dates in November $\left(30 \mathrm{~kg} \mathrm{~N} \mathrm{ha}^{-1}\right)$ and March $\left(75 \mathrm{~kg} \mathrm{~N} \mathrm{ha}^{-1}\right)$. No $N$ fertilizer was applied to the cauliflower crop, except on lysimeters L5 and L6 (90 $\mathrm{kg} \mathrm{N} \mathrm{ha}^{-1}$ ) to ensure sufficient $N$ availability, because all ART3 residues (aboveground and stump) were exported. No phosphorus fertilization was required due 
to its already high concentration in the soil. At each crop harvest, all aboveground plant parts were removed and separated into leaf, stem and head portions. For ART3 (and ART1 or ART2 at the end of the experiment), stumps were also removed. "Crop residues" correspond only to "aboveground residues" after the first and second cycles. After the third cycle, the stump is removed and then considered part of "crop residues" as well. Biomass was then subsampled for DM and chemical analyses, as described above. Once subsampled, crop residues were immediately returned to the lysimeters and incorporated into the soil.

\subsection{Weather}

Meteorological data were obtained at the experimental station. The study site has a temperate humid oceanic climate. During the 1998-2004 study period, mean monthly air temperature ranged from 6.2 to $18{ }^{\circ} \mathrm{C}$, and mean monthly precipitation ranged from 10.4 to $220.8 \mathrm{~mm}$. Mean annual air temperature during this period was $11.7^{\circ} \mathrm{C}$. Cumulative autumn and winter precipitation varied from 693 to $1088 \mathrm{~mm}$. During the study period, cumulative precipitation for cauliflower on lysimeters L2/L4/L6 (July 2001-February 2002) was $414 \mathrm{~mm}$ less than that on lysimeters L1/L3/L5 (July 2000-February 2001). Precipitation differences were also observed for ART2 and ART3 (July 1999-June 2000). They were less than $130 \mathrm{~mm}$ between L1 and L2 (ART2) but ranged from 252 to $444 \mathrm{~mm}$ when L1 or L2 were compared to L5 or L6 for ART3. Drainage water collected from the lysimeters for each crop during the experiment varied from 78 to $801 \mathrm{~mm}$. A portion of cropping cycles for ART2, ART3 and cauliflower had a common drainage period (October to MarchApril). ART1 growth occurred entirely outside of this period. From 1998 to 2004, mean soil temperature at a depth of $10 \mathrm{~cm}$ was $13^{\circ} \mathrm{C}$, which was similar to the mean air temperature $\left(12{ }^{\circ} \mathrm{C}\right)$.

\subsection{Water Sampling and Analytical Procedures}

Drainage water was collected in tanks, sampled twice per month and stored at $4{ }^{\circ} \mathrm{C}$. Ammonium and nitrate contents were analyzed by continuous flow colorimetry (Technicon Auto-Analyser II, Seal Analytical, Mequon, WI, USA). Since ammonium concentration in the water was low, the isotopic composition of the ammonium pool was not determined. Isotopic composition of nitrate $N$ was measured after concentration by evaporation and the reduction of nitrate to ammonium with the reducing Devarda's alloy in an alkaline medium. The ${ }^{15} \mathrm{~N}$ enrichment of nitrate was determined after diffusion [43], as modified by [44], and subsequent analysis was performed with an elementary analyzer (C. E. 1500 NA, Carlo Erba, Milan, Italy) interfaced with an isotope ratio mass spectrometer (Optima, Micromass, Cheshire, UK).

\subsection{Calculations of ${ }^{15} \mathrm{~N}$ Recovery and Leaching in Plants and Water}

The fate of ${ }^{15} \mathrm{~N}$-labeled cauliflower residues was calculated from the amount of ${ }^{15} \mathrm{~N}$ recovered in aboveground plant biomass, the topsoil layer and drainage water. A correction factor of 0.0025 atom\% was applied to the values of atom\% excess of all samples to account for the natural abundance of ${ }^{15} \mathrm{~N}$ in soils, which is slightly higher than that of the air $[4,45,46]$. The percentage of $N$ from the ${ }^{15} N$-labeled artichoke residues recovered in each compartment (i.e., aboveground plant biomass, topsoil layer, drainage water) was calculated as

$$
\left(N_{\text {recovery }} \%\right)_{\text {compartment }}=\frac{N_{\text {compartment }} \times\left[(\text { atom } \% \text { excess })_{\text {compartment }}-0.0025\right]}{N_{\text {art.residue }} \times\left[(\text { atom } \% \text { excess })_{\text {art.residue }}-0.0025\right]} \times 100
$$

where

- $\quad N_{X}$ is the amount of $N$ measured in compartment $\mathrm{X}\left(\mathrm{kg} \mathrm{N} \mathrm{ha}^{-1}\right.$ for a given period; e.g., harvest, water drainage); 
- (atom\% excess) $\mathrm{X}$ is the percentage of ${ }^{15} \mathrm{~N}$ in compartment $\mathrm{X}$ above the natural abundance in the atmosphere (reference material considered to have 0.3663 atom $\%$ of ${ }^{15} \mathrm{~N}$ atoms out of the total number of $N$ atoms in the sample).

Residual ${ }^{15} \mathrm{~N}$ in the soil was calculated as the ${ }^{15} \mathrm{~N}$ applied in artichoke residues minus that lost through plant exportation and leaching, assuming that gaseous losses of ${ }^{15} \mathrm{~N}$ (e.g., denitrification of artichoke-residue $N$ ) were negligible:

$$
\left(N_{\text {recovery } \%}\right)_{\text {soil }}=100-\left(N_{\text {recovery } \%}\right)_{\text {plant }}-\left(N_{\text {recovery } \%}\right)_{\text {leaching }}-\left({ }^{15} N_{\text {art.residue }} \%\right)_{\text {gaseous losses }}
$$

We assumed that denitrification of artichoke-residue $N$ was negligible based on results of a similar ${ }^{15} \mathrm{~N}$ experiment [4]. The protocol of the current experiment was designed to minimize denitrification losses. A well-aerated soil that minimized anaerobic conditions was used, as usually practiced in such vegetable cropping systems. The artichoke residues were finely chopped and mixed with the $10 \mathrm{~cm}$ of topsoil to enhance nitrogen absorption by soil organisms. The limited and fractionated mineral fertilization was expected to minimize periods of excess soil nitrogen.

Residual ${ }^{15} \mathrm{~N}$ in the soil was initially deduced from soil samples, nitrogen content and ${ }^{15} \mathrm{~N}$ analysis. The measurements of total nitrogen content in the soil were considered insufficiently reliable to close the nitrogen balance of the lysimeters, perhaps due to excessive soil heterogeneity. Therefore, we chose to deduce soil nitrogen content from plant and water ${ }^{15} \mathrm{~N}$ analysis, since we considered that soil ${ }^{15} \mathrm{~N}$ deduced from other observations (i.e., plants, water) was more robust than that calculated from soil observations during the experiment.

Exhaustive information from the experiment (i.e., raw data and calculation procedures) is openly available (see below, "Data Availability Statement").

\section{Results}

\subsection{Crop Production and Biomass}

Due to the experimental design, the main features of crop production were observed on each lysimeter but not during the same year or with the same amount of artichoke residues. The lack of replicates prevented analysis of differences in these features. Large standard deviations (SD) in the results illustrated the high variability possible in commercial artichoke production due to interactions among agricultural practices (e.g., dates of planting, fertilization, treatments), climate and cropping conditions. Thus, we used mean values to analyze the fate of nitrogen from artichoke residues and values from individual lysimeters (Table 2) to assess ranges of values. 


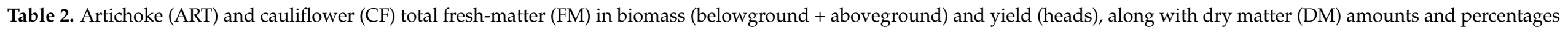
returned to the soil as residues.

\begin{tabular}{|c|c|c|c|c|c|c|c|c|c|c|}
\hline Lysimeter & Planting Date & Harvest Date & $\begin{array}{l}\text { Residues } \\
\text { Provided }\end{array}$ & $\begin{array}{c}\text { Crop } \\
\text { Rotation }\end{array}$ & $\begin{array}{c}\text { Total FM } \\
\left.\text { (t ha- } \mathbf{a}^{-1}\right)\end{array}$ & $\begin{array}{l}\text { Yield FM } \\
\left(\mathrm{t} \mathbf{h a}^{-1}\right)\end{array}$ & $\begin{array}{c}\text { Aboveground } \\
\left.\text { Total DM (t ha }{ }^{-1}\right)\end{array}$ & $\begin{array}{c}\text { Stump DM } \\
\left(t \mathbf{h a}^{-1}\right)\end{array}$ & $\begin{array}{l}\text { Crop Residue } \\
\left.\text { DM (t ha } a^{-1}\right)\end{array}$ & $\begin{array}{l}\text { Aboveground } \\
\text { Residues in } \\
\text { Total DM (\%) }\end{array}$ \\
\hline \multirow[t]{4}{*}{ L1 } & September 1998 & July 1999 & \multirow[t]{4}{*}{$\mathrm{R}_{\mathrm{ART} 1}$} & ART2 & 26.3 & 9.3 & 4.9 & - & 3.1 & 62.5 \\
\hline & July 1999 & June 2000 & & ART3 & 13.6 & 4.2 & 2.2 & $\underline{3.9 *}$ & 1.6 & 72.8 \\
\hline & July 2000 & February 2001 & & $\mathrm{CF}$ & 74.8 & 24.6 & 5.9 & - & 3.8 & 64.5 \\
\hline & March 2001 & September 2001 & & ART1 & 44.9 & 11.2 & 9.1 & 6.8 & 7.2 & 78.6 \\
\hline \multirow[t]{3}{*}{ L2 } & October 1999 & July 2000 & \multirow[t]{3}{*}{$\mathrm{R}_{\mathrm{ART} 1}$} & ART2 & 24.4 & 8.8 & 4.4 & - & 2.8 & 63.8 \\
\hline & July 2000 & June 2001 & & ART3 & 16.2 & 9.2 & 4.4 & $\underline{5.3 *}$ & 1.9 & 43.5 \\
\hline & March 2002 & September 2002 & & ART1 & 38.7 & 12.4 & 8.8 & 6.1 & 5.9 & 67.3 \\
\hline \multirow[t]{4}{*}{ L3 } & July 1999 & June 2000 & \multirow{4}{*}{$\mathrm{R}_{\mathrm{ART} 2}$} & ART3 & 12.1 & 5.0 & 2.5 & $4.4^{*}$ & 1.5 & 61.3 \\
\hline & July 2000 & February 2001 & & $\mathrm{CF}$ & 76.1 & 24.4 & 6.2 & - & 4.2 & 67.1 \\
\hline & March 2001 & September 2001 & & ART1 & 42.1 & 14.9 & 9.6 & - & 6.8 & 70.9 \\
\hline & September 2001 & July 2002 & & ART2 & 49.6 & 12.2 & 10.0 & 9.2 & 7.8 & 78.3 \\
\hline \multirow[t]{3}{*}{ L4 } & July 2000 & June 2001 & \multirow{3}{*}{$\mathrm{R}_{\mathrm{ART} 2}$} & ART3 & 15.3 & 7.4 & 3.9 & $6.5^{*}$ & 2.3 & 58.0 \\
\hline & July 2001 & February 2002 & & $\mathrm{CF}$ & 54.1 & 21.0 & 6.0 & - & 3.9 & 63.9 \\
\hline & March 2002 & September 2002 & & ART1 & 33.1 & 11.5 & 8.2 & - & 6.0 & 73.7 \\
\hline \multirow[t]{4}{*}{ L5 } & July 2000 & February 2001 & \multirow[t]{4}{*}{$\mathrm{R}_{\mathrm{ART} 3}$} & $\mathrm{CF}$ & 73.3 & 26.7 & 5.6 & - & 3.4 & 60.7 \\
\hline & March 2001 & September 2001 & & ART1 & 42.2 & 13.1 & 8.7 & - & 6.4 & 73.6 \\
\hline & September 2001 & July 2002 & & ART2 & 52.8 & 14.8 & 10.3 & - & 7.8 & 75.2 \\
\hline & July 2002 & July 2003 & & ART3 & 29.3 & 14.2 & 6.7 & $\underline{7.7 *}$ & 4.0 & 59.1 \\
\hline \multirow[t]{4}{*}{ L6 } & July 2001 & February 2002 & \multirow[t]{4}{*}{$\mathrm{R}_{\mathrm{ART} 3}$} & $\mathrm{CF}$ & 72.3 & 26.7 & 7.7 & - & 5.0 & 64.7 \\
\hline & March 2002 & September 2002 & & ART1 & 31.5 & 10.9 & 7.1 & - & 5.2 & 73.3 \\
\hline & September 2002 & July 2003 & & ART2 & 28.3 & 9.8 & 6.1 & - & 4.1 & 68.4 \\
\hline & July 2003 & July 2004 & & ART3 & 26.5 & 11.5 & 7.4 & $\underline{5.8 *}$ & 3.3 & 44.7 \\
\hline
\end{tabular}

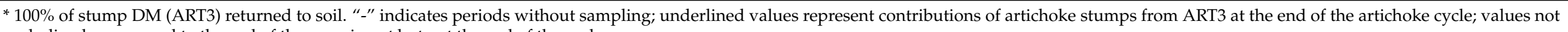
underlined correspond to the end of the experiment but not the end of the cycle. 
ART1 fresh matter $(\mathrm{FM})$ yield (mean $\pm 1 \mathrm{SD}=12.3 \pm 1.5 \mathrm{t} \mathrm{ha}^{-1}$ ) (Table 2$)$ and mean aboveground total DM $\left(8.6 \pm 1.5 \mathrm{t} \mathrm{ha}^{-1}\right)$ were influenced slightly by year. More than $70 \%$ of aboveground DM $\left(6.3 \pm 1.1 \mathrm{t} \mathrm{ha}^{-1}\right)$ was returned to the soil. ART2 mean FM yield on lysimeters L2/L4/L6 was $2.5 \mathrm{t} \mathrm{ha}^{-1}$ less than that on L1/L3/L5, which had a mean FM yield of $10.8 \pm 2.3 \mathrm{t} \mathrm{ha}^{-1}$. ART2 total aboveground DM was $7.2 \pm 2.6 \mathrm{t} \mathrm{ha}^{-1}$, and $70 \%$ of it was returned to the soil as residues. ART3 FM yield was $8.6 \pm 3.8 \mathrm{tha}^{-1}$, and the mean difference between yields on lysimeters L2/L4/L6 and L1/L3/L5 was $1.6 \mathrm{t} \mathrm{ha}^{-1}$. Total aboveground DM for ART3 was $4.5 \pm 2.3 \mathrm{t} \mathrm{ha}^{-1}$. It was higher on lysimeters L2/L4/L6 than on L1/L3/L5. No difference was observed in total stump DM produced on lysimeters L2/L4/L6 vs. L1/L3/L5. ART3 total DM of stumps was $5.6 \pm 1.4 \mathrm{tha}^{-1}$ and represented $57 \%$ of total DM (stump and aboveground). All ART3 stump biomass was chopped and returned to the soil. Total DM returned to the soil as residues from ART3 was $8.0 \pm 2.4 \mathrm{t} \mathrm{ha}^{-1}$ ( $2.4 \mathrm{t} \mathrm{ha}^{-1}$ from aboveground and $5.6 \mathrm{t} \mathrm{ha}^{-1}$ from stumps).

Cauliflower FM yield was $24.8 \pm 2.1 \mathrm{t} \mathrm{ha}^{-1}$. Despite a one-year shift between lysimeters L1/L3/L5 (2000-2001) and L2/L4/L6 (2001-2002) (Table 2), only small differences in cauliflower FM yield were observed between them. Cauliflower FM yield was influenced little by year, even during the low-precipitation season of July 2001 to February 2002, except for L4 (21.0 $\mathrm{t} \mathrm{ha}^{-1}$, compared to the other lysimeters' range of 24.4-26.7 $\left.\mathrm{t} \mathrm{ha}^{-1}\right)$. Total DM of cauliflower was $6.5 \pm 0.8 \mathrm{tha}^{-1}$ and was not influenced by year, even on L4. Cauliflower residues returned to the soil $\left(4.1 \pm 0.6 \mathrm{t} \mathrm{ha}^{-1}\right)$ were similar among years and represented a mean of $64 \%$ of total aboveground DM.

\subsection{Nitrogen Uptake}

Annual $N$ uptake by artichoke total aboveground biomass was less than that by cauliflower; it decreased from $103 \pm 9$ to $73 \pm 30 \mathrm{~kg} \mathrm{~N} \mathrm{ha}^{-1}$ from ART1 to ART3, respectively (Table 3). ART3 stump uptake was $46 \pm 12 \mathrm{~kg} \mathrm{~N} \mathrm{ha}^{-1}$. $N$ returned to the soil by

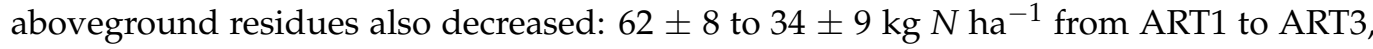
respectively. The percentage of $N$ in residues also decreased from $60 \%$ to $50 \%$ of total $N$ uptake by aboveground biomass from ART1 to ART3. The amount of $N$ returned to the soil during ART3 (aboveground and stump) was $80 \pm 21 \mathrm{~kg} \mathrm{~N} \mathrm{ha}^{-1}$. 


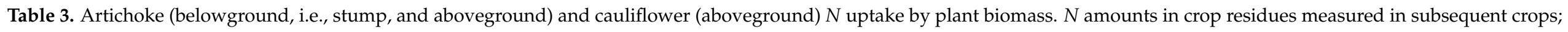

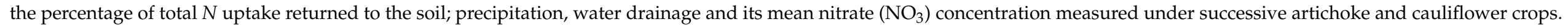

\begin{tabular}{|c|c|c|c|c|c|c|c|c|c|c|c|}
\hline Lysimeter & Planting Date & Harvest Date & $\begin{array}{l}\text { Residues } \\
\text { Provided }\end{array}$ & $\begin{array}{c}\text { Crop } \\
\text { Rotation }\end{array}$ & $\begin{array}{c}\text { Aboveground } \\
N \text { Uptake } \\
\left(\mathrm{kg} N \mathrm{ha}^{-1)}\right.\end{array}$ & 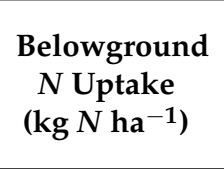 & $\begin{array}{c}N \text { in } \\
\text { Aboveground } \\
\text { Residues } \\
\left(\mathbf{k g} N \mathrm{ha}^{-1}\right)\end{array}$ & $\begin{array}{c}N \text { in } \\
\text { Aboveground } \\
\text { Residues } \\
(\%)\end{array}$ & $\begin{array}{l}\text { Precipitation } \\
(\mathrm{mm})\end{array}$ & $\begin{array}{c}\text { Water } \\
\text { Drainage } \\
(\mathrm{mm})\end{array}$ & $\begin{array}{c}\text { Mean } \mathrm{NO}_{3} \\
\left(\mathrm{mg} \mathrm{L}^{-1}\right)\end{array}$ \\
\hline \multirow{3}{*}{ L1 } & July 1999 & June 2000 & \multirow{3}{*}{$\mathrm{R}_{\mathrm{ART} 1}$} & ART3 & 57 & $31.1 *$ & 33 & 58 & 1060 & 520 & 87.2 \\
\hline & July 2000 & February 2001 & & CF & 260 & - & 145 & 56 & 854 & 536 & 2.5 \\
\hline & March 2001 & September 2001 & & ART1 & 104 & 62.0 & 70 & 67 & 447 & 225 & 24.7 \\
\hline \multirow[t]{4}{*}{ L2 } & October 1999 & July 2000 & \multirow[t]{4}{*}{$\mathrm{R}_{\mathrm{ART} 1}$} & ART2 & 60 & - & 34 & 56 & 899 & 469 & 57.6 \\
\hline & July 2000 & June 2001 & & ART3 & 68 & $\underline{48.8 *}$ & 27 & 40 & 1186 & 783 & 51.0 \\
\hline & July 2001 & February 2002 & & $\mathrm{CF}$ & 185 & - & 100 & 54 & 440 & 79 & 0.8 \\
\hline & March 2002 & September 2002 & & ART1 & 121 & 55.3 & 73 & 60 & 405 & 150 & 13.3 \\
\hline \multirow[t]{4}{*}{ L3 } & July 1999 & June 2000 & \multirow{4}{*}{$\mathrm{R}_{\text {ART2 }}$} & ART3 & 43 & $39.1 *$ & 27 & 63 & 1060 & 468 & 98.8 \\
\hline & July 2000 & February 2001 & & $\mathrm{CF}$ & 262 & - & 150 & 57 & 854 & 510 & 3.3 \\
\hline & March 2001 & September 2001 & & ART1 & 103 & - & 55 & 54 & 447 & 226 & 24.5 \\
\hline & September 2001 & July 2002 & & ART2 & 119 & 77.4 & 79 & 66 & 706 & 80 & 26.7 \\
\hline \multirow[t]{3}{*}{ L4 } & July 2000 & June 2001 & \multirow[t]{3}{*}{$\mathrm{R}_{\text {ART2 }}$} & ART3 & 51 & $43.8 *$ & 28 & 54 & 1186 & 801 & 33.1 \\
\hline & July 2001 & February 2002 & & $\mathrm{CF}$ & 140 & - & 72 & 51 & 440 & 86 & 3.3 \\
\hline & September 2002 & July 2003 & & ART2 & 85 & 43.6 & 51 & 60 & 760 & 295 & 38.6 \\
\hline \multirow[t]{4}{*}{ L5 } & July 2000 & February 2001 & \multirow[t]{4}{*}{$\mathrm{R}_{\mathrm{ART} 3}$} & $\mathrm{CF}$ & 189 & - & 89 & 47 & 854 & 551 & 1.5 \\
\hline & March 2001 & September 2001 & & ART1 & 98 & - & 54 & 55 & 447 & 226 & 18.8 \\
\hline & September 2001 & July 2002 & & ART2 & 108 & - & 64 & 60 & 706 & 105 & 22.3 \\
\hline & July 2002 & July 2003 & & ART3 & 102 & $\underline{47.1 *}$ & 49 & 48 & 808 & 316 & 33.5 \\
\hline \multirow[t]{4}{*}{ L6 } & July 2001 & February 2002 & \multirow[t]{4}{*}{$\mathrm{R}_{\mathrm{ART} 3}$} & $\mathrm{CF}$ & 222 & - & 120 & 54 & 440 & 78 & 1.2 \\
\hline & March 2002 & September 2002 & & ART1 & 100 & - & 66 & 66 & 405 & 146 & 22.9 \\
\hline & September 2002 & July 2003 & & ART2 & 94 & - & 61 & 64 & 760 & 298 & 102 \\
\hline & July 2003 & July 2004 & & ART3 & 118 & $67.4 *$ & 41 & 35 & 742 & 260 & 62.2 \\
\hline
\end{tabular}

* $100 \%$ of stump DM (ART3) returned to soil. "-" indicates periods without sampling; underlined values represent contributions of artichoke stumps from ART3 at the end of the artichoke cycle. 
$N$ uptake by cauliflower was $237 \pm 41 \mathrm{~kg} \mathrm{~N} \mathrm{ha}^{-1}$ on lysimeters L1/L3/L5 and $183 \pm$ $41 \mathrm{~kg} \mathrm{~N} \mathrm{ha}^{-1}$ on L2/L4/L6 (Table 3). The greatest difference in $N$ uptake (122 $\mathrm{kg} \mathrm{N} \mathrm{ha}^{-1}$ ) was observed between L3 and L4, which also had the highest and lowest FM production, respectively. Cauliflower residues contained $113 \pm 31 \mathrm{~kg} \mathrm{~N}$ ha $^{-1}$, representing $53 \%$ of $N$ uptake (Table 3). Cauliflower $N$ uptake was influenced by growing conditions, but not the $N$ contained in its residues.

\subsection{Uptake of ${ }^{15} \mathrm{~N}$}

The repeatability of ${ }^{15} \mathrm{~N}$ recovery in plant parts or leaching was considered acceptable despite differences in weather between the two replicates (Tables 4 and 5). The percentage of ${ }^{15} \mathrm{~N}$ labeled recovered aboveground (Table 4) decreased from ART1 to ART3 (3.04 \pm $0.92 \%$ to $1.87 \pm 0.45 \%$ of ${ }^{15} \mathrm{~N}$ from one harvest's residue). ${ }^{15} \mathrm{~N}$ uptake by aboveground biomass was the highest from the residues most recently applied ( $\mathrm{R}_{\mathrm{ART} 1}: 3.4 \pm 0.2 \%$ in ART2; $\mathrm{R}_{\text {ART2 }}: 2.2 \pm 0.2 \%$ in ART3). ART1 ${ }^{15} \mathrm{~N}$ uptake by aboveground biomass was the highest from $\mathrm{R}_{\mathrm{ART} 3}$ residues $(3.9 \pm 1.0 \%)$. It probably benefited from $\mathrm{R}_{\mathrm{ART} 3}{ }^{15} \mathrm{~N}$ that had been returned via cauliflower residues (Table 3). The ${ }^{15} \mathrm{~N}$ uptake by artichoke stumps was considerable, representing a mean of $34-44 \%$ of all artichoke ${ }^{15} \mathrm{~N}$ uptake. Stump uptake in ART3 slightly decreased from $\mathrm{R}_{\mathrm{ART}}$ to $\mathrm{R}_{\mathrm{ART} 3}$ (from $1.4 \pm 0.7 \%$ to $1.1 \pm 0.4 \%$ for $\mathrm{R}_{\mathrm{ART}}$ in ART3 to $\mathrm{R}_{\mathrm{ART}}$ in ART3, respectively), but it remained approximately $1 \%$ regardless of the residue and the cycle (Table 4). The ${ }^{15} \mathrm{~N}$ of one harvest's residues recovered by ART3 (aboveground and stump) remained lower (2.1-4.4\%) than that recovered by cauliflower aboveground biomass (3.9-9.6\%). 


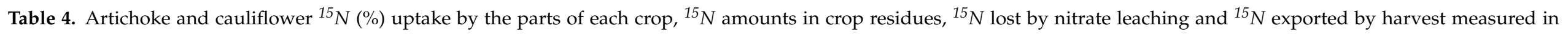
subsequent crops.

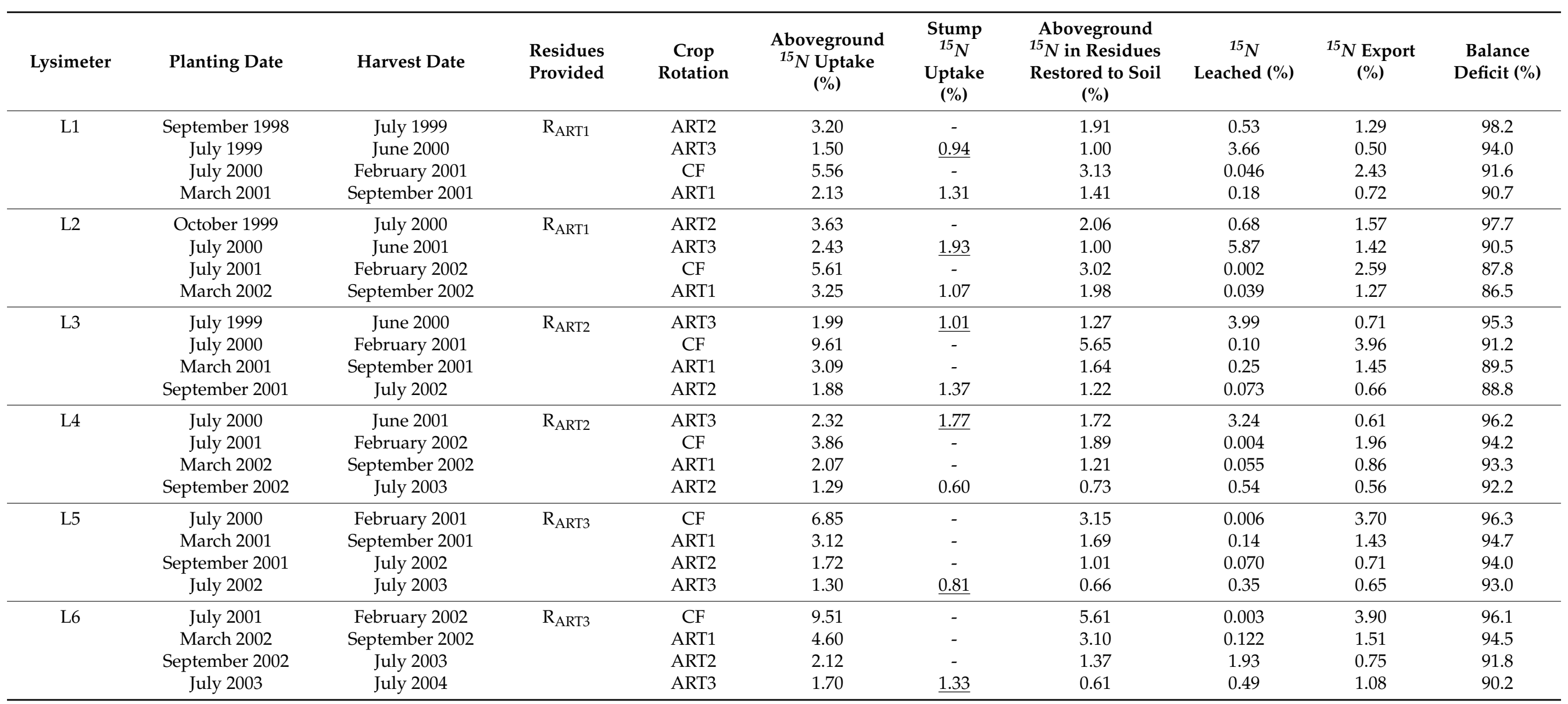

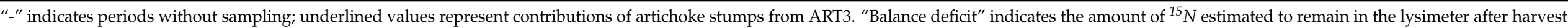
(sum of soil, Equation (2), and aboveground residues). 


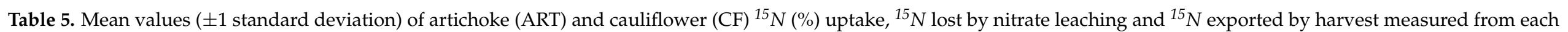
residue.

\begin{tabular}{|c|c|c|c|c|c|c|c|c|c|c|c|c|c|}
\hline \multirow{5}{*}{$\begin{array}{c}\text { Lysimeter } \\
\text { L1-L2 }\end{array}$} & \multirow{5}{*}{$\begin{array}{c}\begin{array}{c}\text { Residues } \\
\text { Provided }\end{array} \\
\mathrm{R}_{\mathrm{ART} 1}\end{array}$} & \multirow[t]{2}{*}{ Process } & \multicolumn{8}{|c|}{ Rotation } & \multicolumn{2}{|c|}{ Total ${ }^{15} N$ per Rotation ${ }^{(2)}$} & \multirow[t]{5}{*}{${ }^{15} \mathrm{~N}$ Conserved ${ }^{(3)}$} \\
\hline & & & \multicolumn{2}{|c|}{ ART2 } & \multicolumn{2}{|c|}{ ART3 } & \multicolumn{2}{|c|}{$\mathrm{CF}$} & \multicolumn{2}{|c|}{ ART1 } & \multirow{4}{*}{$\begin{array}{c}17.5 \% \\
5.9 \% \\
5.5 \% \\
11.4 \%\end{array}$} & \multirow{4}{*}{$\begin{array}{l} \pm 2.73 \% \\
\pm 1.35 \% \\
\pm 1.54 \% \\
\pm 2.91 \% \\
\end{array}$} & \\
\hline & & ${ }^{15} N$ uptake ${ }^{(1)}$ & $4.6 \%$ & $\pm 0.72 \%$ & $3.4 \%$ & $\pm 1.35 \%$ & $5.6 \%$ & $\pm 0.04 \%$ & $3.9 \%$ & $\pm 0.62 \%$ & & & \\
\hline & & ${ }^{15} \mathrm{~N}$ leached & $0.6 \%$ & $\pm 0.11 \%$ & $4.8 \%$ & $\pm 1.56 \%$ & $0.0 \%$ & $\pm 0.03 \%$ & $0.1 \%$ & $\pm 0.10 \%$ & & & \\
\hline & & Total ${ }^{15} N$ loss & $2.0 \%$ & $\pm 0.31 \%$ & $5.7 \%$ & $\pm 2.21 \%$ & $2.5 \%$ & $\pm 0.10 \%$ & $1.1 \%$ & $\pm 0.29 \%$ & & & \\
\hline \multirow[t]{5}{*}{ L3-L4 } & \multirow[t]{5}{*}{$\mathrm{R}_{\mathrm{ART} 2}$} & & \multicolumn{2}{|c|}{ ART3 } & \multicolumn{2}{|c|}{$\mathrm{CF}$} & \multicolumn{2}{|c|}{ ART1 } & \multicolumn{2}{|c|}{ ART2 } & & & \\
\hline & & ${ }^{15} N$ uptake ${ }^{(1)}$ & $3.5 \%$ & $\pm 0.77 \%$ & $6.7 \%$ & $\pm 4.07 \%$ & $3.8 \%$ & $\pm 1.13 \%$ & $2.6 \%$ & $\pm 0.96 \%$ & $16.6 \%$ & $\pm 5.39 \%$ & \\
\hline & & ${ }^{15} \mathrm{~N}$ crop export & $0.7 \%$ & $\pm 0.07 \%$ & $3.0 \%$ & $\pm 1.42 \%$ & $1.2 \%$ & $\pm 0.42 \%$ & $0.6 \%$ & $\pm 0.07 \%$ & $5.4 \%$ & $\pm 1.98 \%$ & \\
\hline & & ${ }^{15} \mathrm{~N}$ leached & $3.6 \%$ & $\pm 0.53 \%$ & $0.1 \%$ & $\pm 0.07 \%$ & $0.2 \%$ & $\pm 0.14 \%$ & $0.3 \%$ & $\pm 0.33 \%$ & $4.1 \%$ & $\pm 0.41 \%$ & $90.5 \%$ \\
\hline & & Total ${ }^{15} N$ loss & $4.3 \%$ & $\pm 0.60 \%$ & $3.0 \%$ & $\pm 1.48 \%$ & $1.3 \%$ & $\pm 0.56 \%$ & $0.9 \%$ & $\pm 0.26 \%$ & $9.5 \%$ & $\pm 2.37 \%$ & \\
\hline \multirow[t]{5}{*}{ L5-L6 } & \multirow[t]{5}{*}{$\mathrm{R}_{\mathrm{ART} 3}$} & & \multicolumn{2}{|c|}{$\mathrm{CF}$} & \multicolumn{2}{|c|}{ ART1 } & \multicolumn{2}{|c|}{ ART2 } & \multicolumn{2}{|c|}{ ART3 } & & & \\
\hline & & ${ }^{15} N$ uptake ${ }^{(1)}$ & $8.2 \%$ & $\pm 1.88 \%$ & $5.1 \%$ & $\pm 1.46 \%$ & $3.1 \%$ & $\pm 0.70 \%$ & $2.6 \%$ & $\pm 0.65 \%$ & $19.0 \%$ & $\pm 4.27 \%$ & \\
\hline & & ${ }^{15} \mathrm{~N}$ crop export & $3.8 \%$ & $\pm 0.14 \%$ & $1.5 \%$ & $\pm 0.05 \%$ & $0.7 \%$ & $\pm 0.03 \%$ & $0.9 \%$ & $\pm 0.31 \%$ & $6.9 \%$ & $\pm 0.53 \%$ & \\
\hline & & ${ }^{15} \mathrm{~N}$ leached & $0.0 \%$ & $\pm 0.00 \%$ & $0.1 \%$ & $\pm 0.01 \%$ & $1.0 \%$ & $\pm 1.31 \%$ & $0.4 \%$ & $\pm 0.10 \%$ & $1.6 \%$ & $\pm 1.40 \%$ & $91.6 \%$ \\
\hline & & Total ${ }^{15} N$ loss & $3.8 \%$ & $\pm 0.15 \%$ & $1.6 \%$ & $\pm 0.04 \%$ & $1.7 \%$ & $\pm 1.35 \%$ & $1.3 \%$ & $\pm 0.41 \%$ & $8.4 \%$ & $\pm 1.93 \%$ & \\
\hline
\end{tabular}

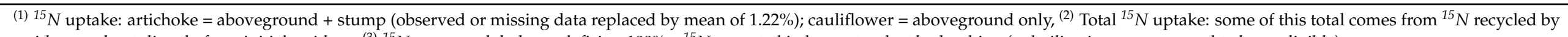
residues and not directly from initial residues, ${ }^{(3)}{ }^{15} \mathrm{~N}$ conserved: balance deficit $=100 \%-{ }^{15} \mathrm{~N}$ exported in harvest or lost by leaching (volatilization was assumed to be negligible). 
More than $36-74 \%$ of ${ }^{15} \mathrm{~N}$ recovered by artichoke aboveground biomass returned to the soil in the residues. A small percentage of ${ }^{15} \mathrm{~N}$ was exported by commercial parts: a mean of $3.0 \%$ in cauliflower heads and similar percentages in artichoke heads $(1.2 \pm 0.3 \%$ to $0.8 \pm 0.4 \%$ from ART1 to ART3, respectively).

In all lysimeters, regardless of the position of cauliflower in the rotation and the nature of residues applied $\left(\mathrm{R}_{\mathrm{ART} 1}, \mathrm{R}_{\mathrm{ART} 2}\right.$ and $\left.\mathrm{R}_{\mathrm{ART} 3}\right)$, recovered ${ }^{15} \mathrm{~N}$ in cauliflower was more than double that in the artichoke crops. ${ }^{15} \mathrm{~N}$ recovered by cauliflower was $6.8 \pm 2.3 \%$ of ${ }^{15} N$ artichoke residues applied to the soil (Table 4). L4 had the lowest $N$ and ${ }^{15} N$ uptake. Approximately half of the ${ }^{15} \mathrm{~N}$-labeled residues taken up by cauliflower or artichoke returned to the soil as residues.

\subsection{Water Drainage and Nitrate Leaching}

Water drainage differed among lysimeters during the rotation and for a given crop. Water drainage ranged from 78 to $551 \mathrm{~mm}$ for the cauliflower cycle (August-February). Mean drainage was six times as high on lysimeters L1/L3/L5 (532 mm in 2000-2001) than on L2/L4/L6 (81 mm in 2001-2002). Precipitation in 2001-2002 was half of that in 2000-2001.

Water drainage differed among artichoke cycles, since ART1 occurred in spring, and 5 months of the cycles of ART2 and ART3 occurred during the drainage period (Table 3). Drainage was lower in ART1 (146-226 mm) than ART2 (80-469 mm) or ART3 (260-801 mm). Weather differences among lysimeters clearly influenced nitrate leaching (Table 3). However, mean values showed that nitrate leaching was negligible with cauliflower and that the risk was highest after ART2 harvest (Figure 2).

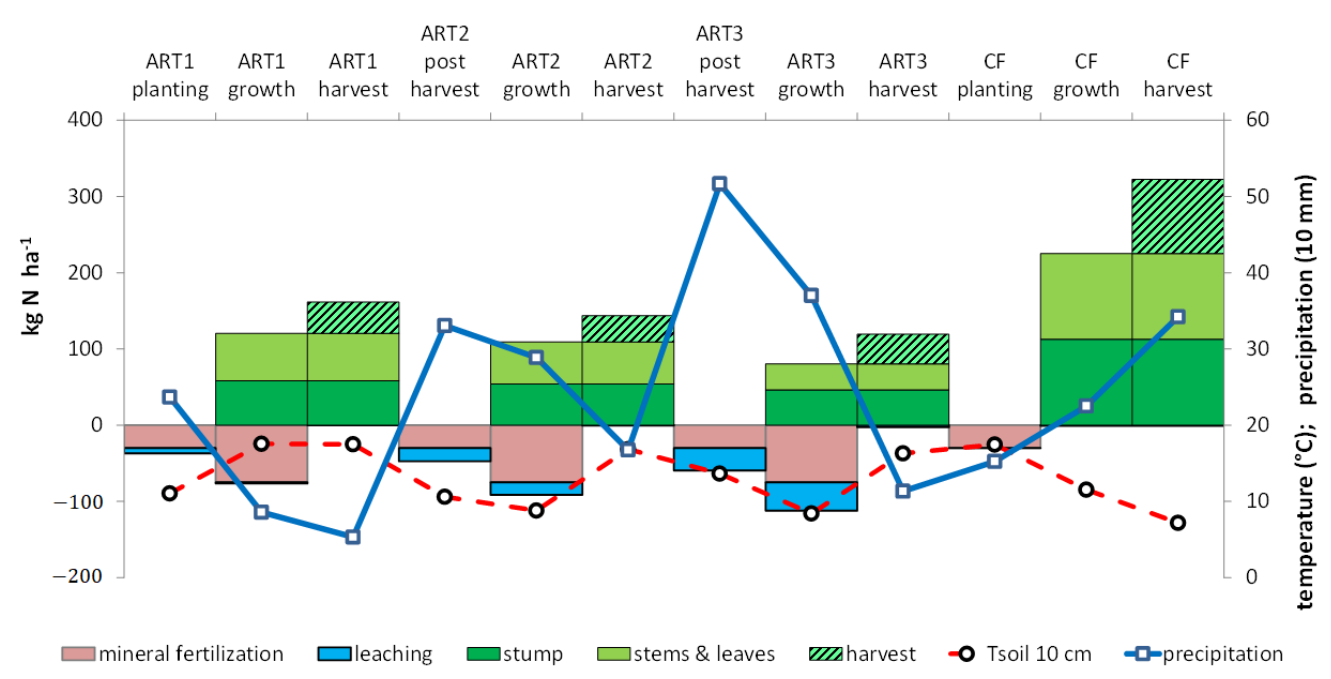

Figure 2. Change in mean soil temperature (Tsoil $10 \mathrm{~cm}$ ), precipitation, $N$ fertilization, uptake and leaching during the artichoke (ART)-cauliflower (CF) rotation.

Mean ${ }^{15} \mathrm{~N}$ from labeled artichoke residues leached in drained water was low for cauliflower, ranging from 0.00 to $0.14 \%$, and it reached $6.2 \%$ after the ART2 harvest (Tables 4 and 5). The ${ }^{15} \mathrm{~N}$ in leached water was influenced by crop cycle and year. It increased over the artichoke cycle from $0.1 \%$ to $3.0 \%$. Mean ${ }^{15} \mathrm{~N}$ leaching from one artichoke harvest's residues was less than $0.1 \%$ in five cauliflower crop lysimeters regardless of the position of cauliflower in the rotation, the weather and the nature of residues $R_{\text {ART1 }}, R_{\text {ART2 }}$ and $\mathrm{R}_{\text {ART3 }}$ (Table 4).

\subsection{Recovery of $N$ at the Rotation Scale}

At the artichoke-cauliflower rotation scale (three years), mean total aboveground DM was similar among lysimeters receiving the same artichoke residues. Cumulative total DM (aboveground and ART3 stumps) of residues returned to the soil by both crops of the 
rotation ranged from 19.6 to $29.3 \mathrm{t} \mathrm{ha}^{-1}$ (Table 2). Mean $N$ uptake by the entire artichokecauliflower rotation on a given lysimeter ranged from 414 to $602 \mathrm{~kg} \mathrm{~N} \mathrm{ha}^{-1}$. Additionally, $47-80 \%$ of annual $N$ uptake returned to the soil in residues, which represented a total of $251-355 \mathrm{~kg} \mathrm{~N} \mathrm{ha}^{-1}$. Cumulative $N$ taken up by crops appeared less variable on lysimeters L1/L2 and L5/L6 than on L3 and L4. Nevertheless, a difference of $152 \mathrm{~kg} \mathrm{~N} \mathrm{ha}^{-1}$ was observed between L3 and L4.

During the three-year artichoke-cauliflower rotation, total uptake of ${ }^{15} \mathrm{~N}$ artichoke residues (from $R_{A R T 1}, R_{A R T 2 \text {, or }} R_{A R T 3}$ ) in artichoke and cauliflower biomass was $18 \pm 5 \%$ (Table 5). When converted into $\mathrm{kg} \mathrm{N} \mathrm{ha}^{-1}$ and averaged over all lysimeters, total uptake reached $30 \%$ of $N$ from residues (Figure 3 ). Total $N$ supplied by each harvest's residues after three years was 20, 11 and $15 \mathrm{~kg} \mathrm{~N} \mathrm{ha}^{-1}$ for $\mathrm{R}_{\mathrm{ART} 1}, \mathrm{R}_{\mathrm{ART} 2}$ and $\mathrm{R}_{\mathrm{ART} 3}$, respectively. Total $N$ supplied by all residues $\left(46 \mathrm{~kg} \mathrm{~N} \mathrm{ha}^{-1}\right.$ ) represented $6 \%$ of total $N$ taken up by crops (747 kg N ha ${ }^{-1}$ during the rotation) and $9 \%$ of total $N$ returned in residues. Cumulative ${ }^{15} \mathrm{~N}$ leaching losses represented $5.7 \%, 4.0 \%$ and $1.3 \%$ of the ${ }^{15} \mathrm{~N}$ applied as ${ }^{15} \mathrm{~N}$ residues from $R_{\text {ART1 }}, R_{\text {ART2 }}$ and $R_{\text {ART3 }}$, respectively (Table 4). Relatively little ${ }^{15} \mathrm{~N}$ in residues was lost via leaching, while large amounts of it were conserved in the soil. Total cumulative ${ }^{15} \mathrm{~N}$ output through plant exportation was moderate, ranging from 5.4 to $6.9 \%$ of the $\mathrm{R}_{\mathrm{ART} 1}$, $\mathrm{R}_{\mathrm{ART} 2}$ and $\mathrm{R}_{\mathrm{ART} 3}$ applied. Residual ${ }^{15} \mathrm{~N}$ remaining in the soil during the rotation was more than $85 \%$ of the ${ }^{15} \mathrm{~N}$ applied.

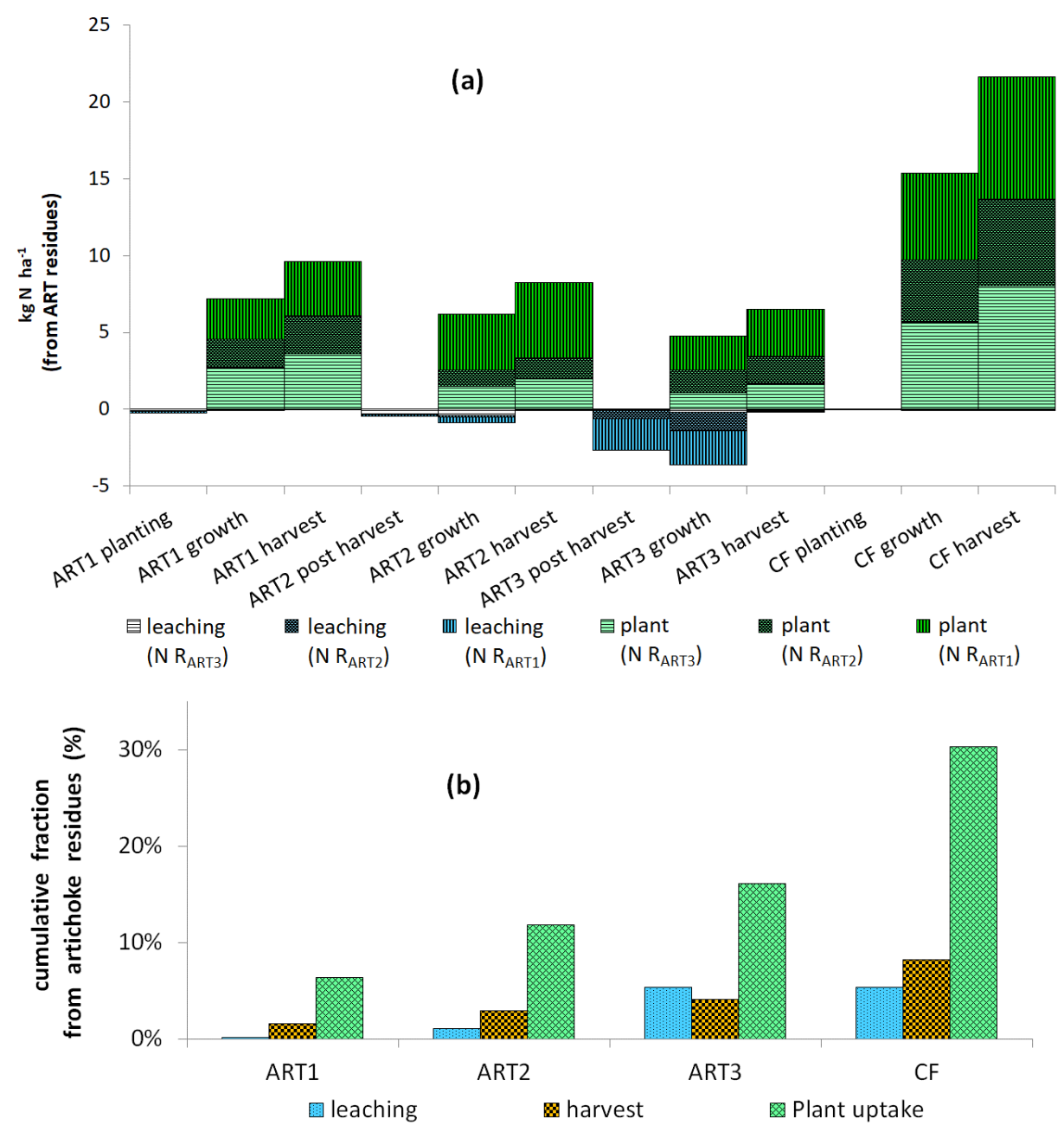

Figure 3. Nitrogen taken from artichoke (ART) residues: (a) distribution of $R_{A R T 1}, R_{A R T 2}$ and $R_{A R T 3}$ in plant and leaching; and (b) cumulative nitrogen from ART residues in leaching, harvest and total plant uptake of ART and cauliflower $(\mathrm{CF})$ crops. $\mathrm{R}_{\mathrm{ART} 1}, \mathrm{R}_{\mathrm{ART} 2}$ and $\mathrm{R}_{\mathrm{ART} 3}$ correspond to the artichoke residues chopped and applied to the soil after the first, second and third harvests, respectively. 


\section{Discussion}

\subsection{Yields and N Accumulation by Crops}

The mean and SD of artichoke biomass among the three cycles, $6.5 \pm 0.8 \mathrm{t} \mathrm{DM} \mathrm{ha}^{-1}$, were similar to those reported by [11], even though artichokes received less $N$ fertilization $\left(105 \mathrm{~kg} \mathrm{~N} \mathrm{ha}^{-1}\right)$ in the present study. As already shown, $N$ fertilization had no significant effect on artichoke stem biomass $[24,47,48]$. Therefore, we assume that ${ }^{15} N$ results were representative of the commercial conditions of artichoke production. ART1 had a shorter cycle (March-September) than ART2 and ART3, but its aboveground biomass took up more $N$ than ART2 or ART3 (Table 3). Artichoke aboveground total DM and $N$ uptake decreased over the artichoke cycles, as previously observed by [13,22]. With more than $60 \%$ of total aboveground artichoke biomass, leaves contain the highest $N$ concentration [22], and more than $50 \%$ of $N$ uptake was returned to the soil as residues. Aboveground-residue $N$ returned to the soil from the three artichoke cycles decreased from ART1 to ART2 to ART3 (62, 55 and $34 \mathrm{~kg} \mathrm{~N} \mathrm{ha}^{-1}$, respectively), a trend observed by [22]. All $N$ contained in stumps in ART3 was returned; thus, ART3 returned more $N$ to the soil $\left(119 \mathrm{~kg} \mathrm{~N} \mathrm{ha}^{-1}\right.$ in aboveground and stump biomass) than ART1 or ART2.

Cauliflower commercial yield exceeded $16 \mathrm{t} \mathrm{FM} \mathrm{ha}^{-1}$ (mean French production, [10]) despite variability in weather and lack of mineral fertilization on lysimeters L1-L4. ART1 yield was also similar to the regional mean [10]. Despite the one-year lag time between lysimeters receiving the same artichoke residues, cauliflower FM and total DM yields were not influenced by year, except cauliflower on lysimeter L4: $N$ uptake, FM and DM decreased following less precipitation than that on L3 (Tables 2 and 3). Cauliflower $N$ in the residues returned to the soil was not influenced by year. Like for most vegetable crops [4], results showed that most $N$ in cauliflower leaves and stems returned to the soil as residues.

At the rotation scale (three years), artichoke and cauliflower residues represented an important source of nutrients: $35-67 \%$ of $N$ uptake in aboveground biomass returned to the soil with residues (414-602 $\mathrm{kg} \mathrm{N} \mathrm{ha}^{-1}$ ). Chopped residues were returned to the soil at different periods: in March for cauliflower and in October for ART1, ART2 and ART3. We assume that the higher residue-use rate by cauliflower and ART1 (2-10\% of residue $N$, compared to $1-4 \%$ by ART2 or ART3) is explained by plant growth (artichoke ART1 at the rosette stage). In ART2 and ART3, the fraction of $N$ mineralized from artichoke residues was more organized in SOM or leached than absorbed by roots because plant growth was stopped after ART1 or ART2 harvest and aboveground biomass cutting.

\subsection{Recovery of ${ }^{15} \mathrm{~N}$ from Residues by Crops}

After three years, the artichoke-cauliflower rotation took up 30\% of the $N$ supplied by residues of three artichoke cycles (Figure $3 b$ ). At the rotation scale, annual $N$ derived from residues (aboveground and ART3 stumps) $\mathrm{R}_{\mathrm{ART} 1}, \mathrm{R}_{\mathrm{ART2}}$ and $\mathrm{R}_{\mathrm{ART}}$ equaled 6-10 $\mathrm{kg} \mathrm{N} \mathrm{ha}^{-1}$ for artichoke and $22 \mathrm{~kg} \mathrm{~N} \mathrm{ha}^{-1}$ for cauliflower (Figure 2). The corresponding recovery percentages (4-6\% and $14 \%$, respectively) were within those of previous studies, showing that crop $N$ recovery from organic inputs, such as plant residues or manures, is often less than $20 \%[49,50]$.

The present results confirm that variability in residue $N$ taken up by subsequent crops depends on crop ability to take up $N[33,51,52]$. $N$ availability depends on factors such as plant species, time after residue input and climate effects that influence both plant absorption and mineralization of organic $N$ from residues [38].

Cauliflower took up significantly more ${ }^{15} \mathrm{~N}$-labeled artichoke residues, and in less time ( 7 months), than any of the three artichoke cycles (11-12 months), even 2-3 years after application, especially during the drainage period (Figure 2). As observed by [22], $N$ concentration (and thus $N$ uptake) in each artichoke cycle was highest during vegetative growth and decreased after harvest.

Recovery of ${ }^{15} \mathrm{~N}$ in artichoke residues after their application was influenced by the position of a crop in the rotation. Cauliflower and artichoke aboveground ${ }^{15} \mathrm{~N}$ uptake was higher for crops grown sooner after the application of labeled residues. The highest 
cauliflower ${ }^{15} \mathrm{~N}$ uptake occurred after $\mathrm{R}_{\mathrm{ART}}$ residues, when cauliflower benefited from aboveground residues and ${ }^{15} \mathrm{~N}$ of stumps applied to the soil. Similarly, the highest ${ }^{15} \mathrm{~N}$ uptake by artichoke occurred immediately after applying ${ }^{15} \mathrm{~N}$-labeled residues: the highest ${ }^{15} \mathrm{~N}$ uptake by ART1, ART2 and ART3 occurred from $\mathrm{R}_{\mathrm{ART} 3}, \mathrm{R}_{\mathrm{ART} 1}$ and $\mathrm{R}_{\mathrm{ART} 2}$, respectively.

Artichoke residues degrade quickly [24], and $N$ uptake from residues depends on environmental factors such as temperature and soil moisture. At our study site, soil temperatures were relatively warm, with mean temperatures above $7^{\circ} \mathrm{C}$ throughout the year (Figure 2), which probably ensured a minimal rate of soil mineralization regardless of season [53]. Soil mineralization is higher during summer (July to mid-October). During this period, ART1 was at mid-vegetative growth and could absorb the soil N, but ART2 and ART3 were at the end of their cycles and could not. This difference explains the loss of $N$ after harvest of ART2 and ART3.

\subsection{Residual ${ }^{15} N$ Remaining in the Lysimeter after Harvest}

After the first growing season, a mean of $97 \%$ of ${ }^{15} \mathrm{~N}$-labeled residue remained in the lysimeter, and $93 \%$ remained after each rotation. Previous studies $[33,41,51]$ reported that $75-89 \%$ of $N$ applied as crop-residue ${ }^{15} N$ remained in the soil. Approximately $40 \%$ of residue $N$ was recovered in the soil after five growing seasons in other experiments [33]. The contribution of artichoke residues- $2 \%$ of residue $N$ supplied to the crop-was low, which was similar to the $1 \%$ reported by [33] and has no practical significance when making $N$ fertilizer recommendations. More than $60 \%$ of the ${ }^{15} \mathrm{~N}$ taken up by artichoke and cauliflower was returned to the soil as residues. After three years, $70 \%$ of ${ }^{15} \mathrm{~N}$-labeled residues remained in the lysimeter, and less than $20 \%$ of residue $N$ had left the system through harvest and leaching. Similar results have been observed for $N$ in other crop residues [51] and for fertilizer-derived $N$. Two years after application of labeled $N, 60-76 \%$ of labeled $N$ remained in the soil $[54,55]$. Three decades after application, $12-15 \%$ of fertilizer-derived $N$ still resided in SOM [2]. Likewise, legume-residue ${ }^{15} N$ increased soil biomass $N$ by approximately $90 \%$ and microbial biomass $N$ derived from crop-residue ${ }^{15} \mathrm{~N}$ by approximately $70 \%$ [41].

Residues sustain SOM $N$ content better than mineral $N$ does; in a previous study, short-term recovery of residue $N(40 \%)$ was higher than that of fertilizer $N(18 \%)$ after five growing seasons [33], and long-term recoveries of ${ }^{15} \mathrm{~N}$-labeled fertilizer or residues in crops and soil were similar. The amount of $N$ from residues remaining in the soil depends on residue characteristics, such as the $C / N$ ratio. Residues with a high $C / N$ ratio have been shown to immobilize soil $N$ [56]. The break-even point between net $N$ mineralization and $N$ immobilization occurs at $C / N$ ratios of 20-40 [57-59]. Plant residues with $C / N$ ratios above this range can cause net immobilization of mineral $N$ in the soil $[60,61]$. In our study, $\mathrm{C} / \mathrm{N}$ ratios ranged from 20 to 81 (Table 1), which can explain the distribution of ${ }^{15} \mathrm{~N}$ among soil, plant uptake and leaching.

Several studies have shown that SOM is the main source of $N$ in crops [33,62-64]. Humic compounds may be an important source of $N$ over the long term [41]. A mean of $79 \%$ of $N$ in a variety of crops was obtained from soil organic $N$ [33]. In most environments, the quantity of $N$ derived from the soil is often large (100-200 $\mathrm{kg} \mathrm{N} \mathrm{ha}^{-1}$.year $\left.{ }^{-1}\right)$, even at sites with low SOM contents [33]. The low annual contribution of residue $N$ supplied to the crop reflects the long-term role of organic inputs in supplying $N$ and maintaining the SOM content [33]. Residue $N$ maintains and increases $N$ reserves in SOM [65]. Most residues undergo biological transformations within the first year following application, with the remaining residues incorporated into the SOM [66]. However, a significant percentage of ${ }^{15} \mathrm{~N}$ recently applied to the soil may not be extractable [67]. Therefore, maintaining SOM levels will remain a crucial component of sustainable agricultural practices [68]. Environmental sustainability requires $N$ availability to replace mineral fertilizers while limiting the risk of $N$ leaching. 


\subsection{Leaching of ${ }^{15} \mathrm{~N}$}

The nitrate concentration leached under artichoke was higher than that under cauliflower (Table 3). Similar differences in nitrate leaching under crops have been reported in previous studies $[69,70]$. For artichoke, nitrate leaching was influenced by both cycle growth (ART1, ART2 and ART3) and year (precipitation and drainage). Mean nitrate concentration in drainage water from artichoke, during the same period as cauliflower, was much higher $\left(0-4,25-105\right.$ and $26-89 \mathrm{mg} \mathrm{NO}_{3} \mathrm{~L}^{-1}$ for cauliflower, ART2 and ART3, respectively; Table 3).

Differences in leaching were also related to differences in water drainage. Leaching decreased for the same growth stage because of differences in precipitation: for ART1 between L1-L2 (158 mm); for ART2 between L3-L4 (205 mm), L5-L6 (260 mm) and L1-L2 (269 mm); and for ART3 between L3-L4 (332 mm). These differences were explained by a difference in total precipitation in 2001-2002, which was half that in 2000-2001.

In each year of an artichoke crop, artichokes are in the rosette stage from spring to autumn (March/April to October) and completely cover the soil [19]. The highest $N$ uptake rates, decreasing $N$ leaching from mineralized $N$, occurred during this period of highest artichoke growth [22]. Therefore, when artichoke is harvested in July (ART2 and ART3), its cycle includes approximately 5 months without high $N$ uptake during the drainage period after harvest (October-February). Following agricultural practices, all aboveground artichoke biomass is cut, chopped and returned to the soil in mid-October. Only the artichoke stump is left on the ground. Therefore, ART2 and ART3 crops partially cover the ground (20-30\%). During this period, artichoke does not take up $N$ like the cauliflower does, resulting in $N$ leaching (Table 5; Figure 2). This management practice increases the risk of nitrate leaching below the root zone, as reported for other crops [52]. According to [33], most ${ }^{15} \mathrm{~N}$ losses from fertilizers or residues occurred during the year of application. This was not observed in our study, in which the most ${ }^{15} \mathrm{~N}$ leached from residues after the ART2 harvest, which was not immediately after application of ${ }^{15} \mathrm{~N}$-labeled residues, and concerned both ART1 and ART2 residues (Figure 3a). Therefore, the highest peak of $N$ leaching depends on precipitation and soil temperature, and plant uptake can decrease leaching provided cover percentage and growth are sufficient. The representativeness of our results for artichoke production elsewhere depends on the local harvest date and precipitation in autumn and winter.

The ability of soil cover to decrease leaching was confirmed by the leaching results for cauliflower (Figure 3a). Regardless of drainage for cauliflower (78-514 mm), concentrations of leached nitrate were low $\left(<5 \mathrm{mg} \mathrm{NO}_{3} \mathrm{~L}^{-1}\right)$, which is lower than the threshold in the European Nitrates Directive: $50 \mathrm{mg} \mathrm{NO}_{3}{ }^{-} \mathrm{L}^{-1}$. Regardless of cauliflower growing conditions, little ${ }^{15} \mathrm{~N}$ was leached during its cycle, as reported by [4]. Therefore, we can conclude that in climates that allow $N$ mineralization and leaching during autumn and winter, and management practices such as introducing break crops (catch crops) can decrease leaching risk of ART2 and ART3. Other practices that improve synchronization between $N$ mineralization and $N$ sinks will also decrease leaching risk.

\subsection{Reducing N Leaching by Improving Synchronization between Residue Mineralization and Crop Uptake}

Most leaching occurred when plants had low $N$ demand, as previously shown [38]. The lower ${ }^{15} \mathrm{~N}$ recovery of artichoke than that of cauliflower can be related to a lack of synchronization between soil mineralization and artichoke requirements. The percentage of available residue $N$ taken up by a crop depends on how well $N$ mineralization of residues is synchronized with the crop's $N$ demand [71]. However, close synchronization is hard to achieve in many environments [33]. Artichoke and cauliflower ${ }^{15} \mathrm{~N}$ recovery was influenced by growth stage, crop management practices, warm weather conditions and nutrient losses through leaching.

ART2 and ART3 had approximately 5-6 months of low demand at a period with high risk of leaching because of higher drainage (October-February). The high nitrate leaching 
in ART2 and ART3 could be associated with asynchronism between the $N$ released from the soil and residues and the low $N$ demand in the early growth stages that occur after cutting aboveground biomass. Management strategies have been suggested to avoid fallow periods by planting cover crops for the drainage period after artichoke harvest, unlike for cauliflower, which has high $N$ requirements during the drainage period [33]. Appropriate management of cropping systems can minimize nitrate leaching. One plausible solution is cover vegetables that can take up soil $N$ during this period of drainage and low $N$ requirements of ART2 and ART3.

The $C / N$ ratio of residues influences the availability and uptake of $N$ by the first subsequent crop, even if its effect on recovery of ${ }^{15} \mathrm{~N}$ by following crops may be limited [33]. Therefore, another option to decrease $N$ leaching is to stimulate $N$ assimilation by soil organisms. This can be done by increasing the $C / N$ ratio of residues by applying compost. However, variability in compost quality and difficulties associated with incorporating compost with crop residues make this solution less reliable than break crops for short-term improvements.

\section{Conclusions}

Recovery of $N$ derived from artichoke residues was low. Our results, confirmed by a literature review, show that ${ }^{15} \mathrm{~N}$ in residues contributed less to crop $N$ requirements but contributed much more to sustaining and augmenting $N$ reserves in SOM. After three growing seasons of an artichoke-cauliflower rotation, more than $86 \%$ of artichoke-residue $N$ remained in the soil. Approximately $93 \%$ of ${ }^{15} \mathrm{~N}$ recently applied to the soil remained there, and soil $N$ remained the primary $N$ source for crops.

Management practices to increase $N$-use efficiency and reduce $N$ losses remain a challenge. Management practices should be designed to maximize synchronization between the release of $N$ from soil sources and the time of maximum $N$ uptake by crops. Mitigation or restoration measures must consider the delay that results from the legacy of past residue-derived $N$ and applications of mineral fertilizers in agricultural systems. The literature review showed that break crops should be introduced in artichoke-cauliflower rotations to reduce nitrate leaching after the first and second artichoke harvests in regions where autumn and winter precipitation induce a leaching risk. Appropriate management of organic amendments in intensive cropping systems, including crop residues, can play an important role in maximizing production efficiency and minimizing negative environmental impacts. In turn, predictive models should integrate feedbacks between the dynamics of soil temperature, drainage and plant uptake.

Author Contributions: Conceptualization, N.A.-C., P.R. and J.P.S.; methodology, N.A.-C., P.R., J.P.S., J.M.C., T.M. and S.M.-A.; software, N.A.-C., P.R.; validation, T.M., M.S.C. and S.M.-A.; formal analysis, N.A.-C., P.R., J.P.S.; investigation, N.A.-C., J.P.S.; resources, N.A.-C., J.P.S.; data curation, N.A.-C., P.R.; writing—original draft preparation, N.A.-C., P.R.; writing—review—visualization and editing, T.M., M.S.C. and S.M.-A. All authors have read and agreed to the published version of the manuscript.

Funding: This work was financially supported by the authors' institutions.

Institutional Review Board Statement: Not applicable, this study did not involve humans or animals.

Informed Consent Statement: Not applicable, this study did not involve humans or animals.

Data Availability Statement: The data and calculations presented in this study are openly available in data.inrae.fr repository, at [doi:10.15454/5MQJSV], version 3.0.

Acknowledgments: We would like to thank C. Barrier for his help with the experiments.

Conflicts of Interest: The authors declare no conflict of interest. 


\section{References}

1. Galloway, J.N.; Schlesinger, W.H.; Levy, H.; Michaels, A.; Schnoor, J.L. Nitrogen fixation: Anthropogenic enhancementenvironmental response. Glob. Biogeochem Cycles 1995, 9, 235-252. [CrossRef]

2. Sebilo, M.; Mayer, B.; Nicolardot, B.; Pinay, G.; Mariotti, A. Long-term fate of nitrate fertilizer in agricultural soils. Proc. Natl. Acad. Sci. USA 2013, 110, 18185-18189. [CrossRef] [PubMed]

3. Crews, T.E.; Poples, M.B. Can the synchrony of nitrogen supply and crop demand be improved in legume and fertilizer-based agroecosystems? A review. Nutr. Cycl. Agroecosyst. 2005, 72, 101-120. [CrossRef]

4. Akkal-Corfini, N.; Morvan, T.; Menasseri-Aubry, S.; Bissuel-Bélaygue, C.; Poulain, D.; Orsini, F.; Leterme, P. Nitrogen mineralization, plant uptake and nitrate leaching following the incorporation of $\left({ }^{15} \mathrm{~N}\right)$-labeled cauliflower crop residues (Brassica oleracea) into the soil: A 3-year lysimeter study. Plant Soil. 2010, 328, 17-26. [CrossRef]

5. Lanteri, S.; Acquadro, A.; Comino, C.; Mauro, R.; Mauromicale, G.; Portis, E. A first linkage map of globe artichoke (Cynara cardunculus var. scolymus L.) based on AFLP, S-SAP, M-AFLP and microsatellite markers. Theor. Appl. Genet. 2006, 112, 1532-1542. [CrossRef]

6. Azza, A.; El-din, E.; Eman, E.; Aziz, S.F.; Hendawy, E.; Omer, A. Impact of phosphorus nutrition and number of cuttings on growth, yield and active constituents of artichoke. Int. J. Acad. Res. 2010, 2, 240-244.

7. Iapichino, G. Micropropagation of globe artichoke (Cynara cardunculus L. var. scolymus). In Protocols for Micropropagation of Selected Economically-Important Horticultural Plants; Lambardi, M., Ozudogru, E.A., Jain, S.M., Eds.; Humana Press: Totowa, NJ, USA, 2013; Volume 994, pp. 369-380.

8. FAOSTAT. Statistical Database; FAO: Rome, Italy, 2019; Available online: http:/ /faostat.fao.org/en/?\#data/QC (accessed on 4 November 2020).

9. Giorgi, D.; Pandozy, G.; Farina, A.; Grosso, V.; Lucretti, S.; Crinò, P.; Saccardo, F. Karyotype of globe artichoke (Cynara cardunculus var. scolymus): Preliminary studies to define its chromosome morphology. Acta Horticulturae 2013, 133-138. [CrossRef]

10. Agreste, Statistique Agricole Annuelle. Available online: http:/ / agreste.agriculture.gouv.fr (accessed on 26 November 2020).

11. Colla, G.; Rouphael, Y.; Cardarelli, M.; Svecova, E.; Rea, E.; Lucini, L. Effects of saline stress on mineral composition, phenolic acids and flavonoids in leaves of artichoke and cardoon genotypes grown in floating system. J. Sci. Food Agric. 2012, 93, 1119-1127. [CrossRef]

12. Lombardo, S.; Pandino, G.; Mauromicale, G.; Knodler, M.; Carle, R.; Schieber, A. Influence of genotype, harvest time and plant part on polyphenolic composition of globe artichoke (Cynara cardunculus L. var. scolymus (L.) Fiori). Food Chem. 2010, 119, 1175-1181. [CrossRef]

13. Pandino, G.; Lombardo, S.; Mauromicale, G.; Williamson, G. Profile of polyphenols and phenolic acids in bracts and receptacles of globe artichoke (Cynara cardunculus var. scolymus) germplasm. J. Food Compos. Anal. 2011, 24, 148-153. [CrossRef]

14. Ruta, C.; Tagarelli, A.; Campanelli, A.; De Mastro, G.; Morone-Fortunato, I. Callogenesis Capability of Artichoke (Cynara cardunculus var. scolymus L. Fiori). Acta Horticulturae 2013, 377-380. [CrossRef]

15. De Falco, B.; Incerti, G.; Amato, M.; Lanzotti, V. Artichoke: Botanical, agronomical, phytochemical, and pharmacological overview. Phytochem. Rev. 2015, 14, 993-1018. [CrossRef]

16. Soliman, G.; Saad, T.M. Effect of cynara scolymus L. (artichoke) extract on lipid profile of hyperlipidemic male rats. Egypt. J. Hosp. Med. 2009, 37, 733-741.

17. Gominho, J.; Lourenco, A.; Palma, P.; Lourenco, M.E.; Curt, M.D.; Fernandez, J.; Pereira, H. Large scale cultivation of Cynara cardunculus L. for biomass production-A case study. Ind. Crop. Prod. 2011, 33, 1-6. [CrossRef]

18. Gouveia, S.C.; Castilho, P.C. Phenolic composition and antioxidant capacity of cultivated artichoke, Madeira cardoon and artichoke-based dietary supplements. Food Res. Int. 2012, 48, 712-724. [CrossRef]

19. Archontoulis, S.V.; Struik, P.C.; Vos, J.; Danalatos, N.G. Phenological growth stages of Cynara cardunculus: Codification and description according to the BBCH scale. Ann. Appl. Biol. 2010, 156, 253-270. [CrossRef]

20. Duarte, D.; Figueiredo, R.; Pereira, S.; Pissarra, J. Structural characterization of the stigma style complex of Cynara cardunculus (Asteraceae) and immunolocalization of cardosins A and B during floral development. Can. J. Bot. 2006, 84, 737-749. [CrossRef]

21. Angelini, L.G.; Ceccarini, L.; Nassi o Di Nasso, N.; Bonari, E. Long-term evaluation of biomass production and quality of two cardoon (Cynara cardunculus L.) cultivars for energy use. Biomass Bioenergy 2009, 33, 810-816. [CrossRef]

22. Rincon, L.; Perez, A.; Pellicer, C.; Abadia, A.; Saez, J. Nutrient uptake by artichoke. Acta Horticulturae 2007, 287-292. [CrossRef]

23. Archontoulis, S.V.; Vos, J.; Yin, X.; Bastiaans, L.; Danalatos, N.G.; Struik, P.C. Temporal dynamics of light and nitrogen vertical distributions in canopies of sunflower, kenaf and cynara. Field Crop Res. 2011, 122, 186-198. [CrossRef]

24. Mahmoud, E.K.; Abd EL-Kader, N.K. How the nitrogen fertilization dose affects the biochemical composition and net mineralization of the artichoke residues. J. Soil Sci. Plant Nutr. 2012, 12, 23-31. [CrossRef]

25. Thompson, T.L.; Doerge, T.A.; Godin, R.E. Nitrogen and water interactions in subsurface drip-irrigated cauliflower: I. Plant response. Soil Sci. Soc. Am. J. 2000, 64, 406-411. [CrossRef]

26. Li, Z.P.; Han, C.W.; Han, F.X. Organic C and N mineralization as affected by dissolved organic matter in paddy soils of subtropical China. Geoderma 2010, 157, 206-213. [CrossRef]

27. Chaves, B.; De Neve, S.; Boeckx, P.; Berko, C.; Van Cleemput, O.; Hofman, G. Manipulation the $\mathrm{N}$ release from ${ }^{15} \mathrm{~N}$ labelled celery residues by using straw and vinasses. Soil Biol. Biochem. 2006, 38, 2244-2254. [CrossRef] 
28. De Neve, S.; Hofman, G. Modelling N mineralization of vegetable crop residues during laboratory incubation. Soil Biol. Biochem. 1996, 28, 1451-1457. [CrossRef]

29. Rahn, C.R.; Paterson, C.D.; Vaidyanathan, L.V. The use of measurement of soil mineral N in understanding the response of crops to fertilizer nitrogen in intensive cropping rotations. J. Agric. Sci. 1998, 130, 345-356. [CrossRef]

30. Neeteson, J.J.; Carton, O.T. The environmental impact of nitrogen in field vegetable production. Acta Hort. 2001, 563, 21-28. [CrossRef]

31. Rahn, C.R.; Bending, G.D.; Tuner, M.K. Management of N mineralization from crop residues of high $\mathrm{N}$ content using amendment materials of varying quality. Soil Use Manag. 2003, 19, 193-200. [CrossRef]

32. Danalatos, N.G.; Skoufogianni, E.; Giannoulis, K.; Archontoulis, S.V. Responses of Cynara cardunculus to irrigation and Nfertilization in central Greece 2007. In Proceedings of the 15th European Biomass Conference \& Exhibition from Research to Market Deployment, Berlin, Germany, 7-11 March 2007; Available online: http:/ /www.researchgate.net/publication/272942878_ Responses_of_Cynara_cardunculus_to_irrigation_and_N-fertilization_in_central_Greece (accessed on 25 January 2021).

33. Dourado-Neto, D.; Powlson, D.; Abu Bakar, R.; Bacchi, O.O.S.; Basanta, M.V.; Cong, P.; Thi Keerthisinghe, G.; Ismaili, M.; Rahman, S.M.; Reichardt, K.; et al. Multiseason recoveries of organic and inorganic nitrogen-15 in tropical cropping systems. Soil Sci. Soc. Am. J. 2010, 74, 139-152. [CrossRef]

34. Jensen, E.S. Availability of nitrogen in ${ }^{15} \mathrm{~N}$-labelled mature pea residues to subsequent crops in the field. Soil Biol. Biochem. 1994, 26, 465-472. [CrossRef]

35. Stevenson, F.C.; Walley, F.L.; van Kessel, C. Direct vs. indirect nitrogen-15 approaches to estimate nitrogen contributions from crop residues. Soil Sci. Soc. Am. J. 1998, 62, 1327-1334. [CrossRef]

36. Hood, R.C.; Merckx, R.; Jensen, E.S.; Powlson, D.; Matijevic, M.; Hardarson, G. Estimating crop N uptake from organic residues using a new approach to the ${ }^{15} \mathrm{~N}$ isotope dilution technique. Plant Soil. 2000, 223, 33-46. [CrossRef]

37. Kumar, K.; Goh, K.M.; Scott, W.R.; Frampton, C.M. Effects of N-15-labelled crop residues and management practices on subsequent winter wheat yields, nitrogen benefits and recovery under field conditions. J. Agric. Sci. 2001, 136, 35-53. [CrossRef]

38. Jackson, L.E. Fates and losses of nitrogen from a nitrogen-15-labeled cover crop in an intensively managed vegetable system. Soil Sci. Soc. Am. J. 2000, 64, 1404-1412. [CrossRef]

39. Zapata, F.; Hera, C. Enhancing nutrient management through use of isotope techniques. In Nuclear Techniques in Soil-Plant Studies for Sustainable Agriculture and Environmental Preservation, Proceedings of the International Symposium on Nuclear and Related Techniques in Soil-Plant Studies on Sustainable Agriculture and Environmental Preservation. Vienna, Austria, 17-21 October 1994; IAEA: Vienna, Austria, 1995.

40. Lehmann, J.; Muraoka, T. Tracer methods to assess nutrient uptake distribution in multistrata agroforestry systems. Agrofor. Syst. 2001, 53, 133-140. [CrossRef]

41. Azam, F.; Malik, K.A.; Sajjad, M.I. Transformations in soil and availability to plants of is N applied as inorganic fertilizer and legume residues. Plant Soil. 1985, 86, 3-13. [CrossRef]

42. IUSS Working Group WRB. World Reference Base for Soil Resources 2014, update 2015. International soil classification system for naming soils and creating legends for soil maps. In World Soil Resources Reports No. 106; FAO: Rome, Italy, 2015 ; p. 203. Available online: http:/ / www.fao.org/3/i3794en/I3794en.pdf (accessed on 21 December 2020).

43. Brooks, P.D.; Stark, J.M.; McInteer, B.B.; Preston, T. Diffusion method to prepare soil extracts for automated nitrogen-15 analysis. Soil Sci. Soc. Am. J. 1989, 53, 1707-1711. [CrossRef]

44. Sparling, G.P.; Zhu, C.Y.; Fillery, I.R.P. Microbial immobilization of ${ }^{15} \mathrm{~N}$ from legume residues in soils of differing textures: Measurement by persulphate oxidation and ammonia diffusion methods. Soil Biol. Biochem. 1996, 28, 1707-1715. [CrossRef]

45. Morvan, T. Quantification et Modélisation des Flux D’azote Résultant des Épandages de Lisier. Ph.D. Thesis, University of Paris VI, Paris, France, 1999; 146p.

46. Portela, S.I.; Andriulo, A.E.; Sasal, M.C.; Bruno, M.; Jobbagy, E.G. Fertilizer vs. organic matter contributions to nitrogen leaching in cropping systems of the Pampas: ${ }^{15} \mathrm{~N}$ application in field lysimeters. Plant Soil. 2006, 289, 265-277. [CrossRef]

47. Archontoulis, S.; Danalatos, N.G.; Struik, P.; Vos, J.; Yin, X. Agronomy of Cynara cardunculus growing on an aquic soil in central Greece. In Proceedings of the International Conference on Agricultural Engineering, Hersonissos, Crete, Greece, 23-25 June 2008; pp. 1-15. Available online: https://www.researchgate.net/profile/SV_Archontoulis/publication/377901 22_Agronomy_of_Cynara_cardunculus_growing_in_an_aquic_soil_in_central_Greece/links / 02bfe51397069bfd8f000000.pdf (accessed on 25 January 2021).

48. Shinohara, T.; Agehara, S.; Yoo, K.S.; Leskovar, D.I. Irrigation and nitrogen management of artichoke: Yield, head quality, and phenolic content. Hortscience 2011, 46, 377-386. [CrossRef]

49. Haggar, J.P.; Tanner, E.V.J.; Beer, J.W.; Kass, D.C.L. Nitrogen dynamics of tropical agroforestry and annual cropping systems. Soil Biol. Biochem. 1993, 25, 1363-1378. [CrossRef]

50. Vanlauwe, B.; Swift, M.J.; Merckx, R. Soil litter dynamics and N use in a leucaena (Leucaena leucocephala Lam. (DeWitt)) alley cropping system in southwestern Nigeria. Soil Biol. Biochem. 1996, 28, 739-749. [CrossRef]

51. Macdonald, A.J.; Poulton, P.R.; Stockdale, E.A.; Powlson, D.S.; Jenkinson, D.S. The fate of residual ${ }^{15} \mathrm{~N}-l$ labelled fertilizer in arable soils: Its availability to subsequent crops and retention in soil. Plant Soil 2002, 246, 123-137. [CrossRef]

52. Vázquez, N.; Pardo, A.; Suso, M.L.; Quemada, M. A methodology for measuring drainage and nitrate leaching in unevenly irrigated vegetable crops. Plant Soil 2005, 269, 297-308. [CrossRef] 
53. Vanlauwe, B.; Nwoke, O.C.; Sanginga, N.; Merckx, R. Impact of residual quality on the C and N mineralization of leaf and root residues of three agroforestry species. Plant Soil 1996, 183, 221-231. [CrossRef]

54. Hart, P.B.S.; Powlson, D.S.; Poulton, P.R.; Johnson, A.E.; Jenkinson, D.S. The availability of the nitrogen in the crop residues of winter wheat to subsequent crops. J. Agric. Sci. 1993, 121, 355-362. [CrossRef]

55. Glendining, M.J.; Poulton, P.R.; Powlson, D.S.; Macdonald, A.J.; Jenkinson, D.S. Availability of the residual nitrogen from a single application of ${ }^{15} \mathrm{~N}$-labelled fertilizer to subsequent crops in a long-term continuous barley experiment. Plant Soil 2001, 233, 231-239. [CrossRef]

56. Kumar, K.; Goh, K.M. Crop residues and management: Effects on soil quality, soil nitrogen dynamics, crop yield and nitrogen recovery. Adv. Agron. 2000, 68, 198-320.

57. Seneviratne, G. Litter quality and nitrogen release in tropical agriculture: A synthesis. Biol. Fertil. Soils 2000, 31, 60-64. [CrossRef]

58. Van Kessel, J.S.; Reeves, J.B.; Meisinger, J.J. Nitrogen and carbon mineralization of potential manure components. J. Environ. Qual. 2000, 29, 1669-1677. [CrossRef]

59. Qian, P.; Schoenau, J. Availability of nitrogen in solid manure amendments with different C:N ratios. Can. J. Soil Sci. 2002, 82, 219-225. [CrossRef]

60. Jensen, E.S. Dynamics of mature pea residue nitrogen turnover in unplanted soil under field conditions. Soil Biol. Biochem. 1994, 26, 455-464. [CrossRef]

61. McKenney, D.J.; Wang, S.W.; Drury, C.F.; Findlay, W.I. Denitrification, immobilization and mineralization in nitrate limited and non-limited residue-amended soil. Soil Sci. Soc. Am. 1995, 59, 118-124. [CrossRef]

62. Macdonald, A.J.; Poulton, P.; Powlson, D.S.; Jenkinson, D.S. Effects of season, soil type and cropping on recoveries, residues and losses of ${ }^{15} \mathrm{~N}$-labelled fertilizer applied to arable crops in the spring. J. Agric. Sci. 1997, 129, 125-154. [CrossRef]

63. Sanchez, P.A.; Jama, B. Soil fertility replenishment takes off in East and southern Africa. In Integrated Plant Nutrient Management in Sub-Saharan Africa: From Concept to Practice; Vanlauwe, B., Ed.; CAB Int.: Wallingford, UK, 2002; pp. $23-46$.

64. Stevens, W.B.; Hoeft, R.G.; Mulvaney, R.L. Fate of nitrogen-15 in a long-term nitrogen rate study: II. Nitrogen uptake efficiency. Agron. J. 2005, 97, 1046-1053. [CrossRef]

65. Janzen, H.H.; Bole, J.B.; Biederbeck, V.O.; Slinkard, E. Fate of N applied as green manure or ammonium sulfate fertilizer to soil subsequently cropped with spring wheat in three sites in western Canada. Can. J. Soil Sci. 1990, 70, 313-323. [CrossRef]

66. Ladd, J.N.; Amato, M. The fate of nitrogen from legume and fertilizer sources in soils successively cropped with wheat under field conditions. Soil Biol. Biochem. 1986, 18, 417-425. [CrossRef]

67. Thönnissen, C.; Midmore, D.J.; Ladha, J.K.; Olk, D.C.; Schmidhalter, U. Legume decomposition and nitrogen release when applied as green manures to tropical vegetable production systems. Agron. J. 2000, 92, 253-260. [CrossRef]

68. Swift, M.J.; Woomer, P. Organic matter and the sustainability of agricultural systems: Definition and measurement. In Soil Organic Matter Dynamics and Sustainability of Tropical Agriculture; Mulongoy, K., Merckx, R., Eds.; John Wiley \& Sons: Chichester, UK, 1993; pp. 3-18.

69. Min, J.; Zhang, H.L.; Shi, W.M. Optimizing nitrogen input to reduce nitrate leaching loss in greenhouse vegetable production. Agr. Water Manag. 2012, 111, 53-59. [CrossRef]

70. Yang, X.L.; Lu, Y.L.; Tong, Y.A.; Yin, X.F. A 5-year lysimeter monitoring of nitrate leaching from wheat-maize rotation system: Comparison between optimum $\mathrm{N}$ fertilization and conventional farmer N fertilization. Agric. Ecosyst. Environ. 2015, 199, 34-42. [CrossRef]

71. Giller, K.E.; Cadish, G. Future benefits from biological nitrogen fixation: An ecological approach to agriculture. Plant Soil 1995, 174, 255-277. [CrossRef] 